ROCZNIKI HISTORYCZNE

Rocznik LXXXII — 2016

PIOTR OKNIŃSKI (Instytut Historii PAN, Warszawa)

\title{
Glówne etapy formowania się miasta lokacyjnego w Sandomierzu w XIII-XIV wieku ${ }^{1}$
}

Zarys treści: Artykuł ma na celu podsumowanie i weryfikację stanu badań nad lokacją Sandomierza. Średniowieczna lokacja miejska została ukazana jako skomplikowany, rozciągnięty w czasie proces. Autor wyróżnia trzy główne etapy formowania miasta lokacyjnego.

Content outline: The aim of the paper is to sum up and verify the current state of research on the location of Sandomierz. Medieval town location is shown as a complicated and longlasting process. The author identifies three main stages in the formation of the locational town.

Słowa kluczowe: kancelaria miejska, kościół parafialny, lokacja, miasto, pieczęć miejska, prawo magdeburskie, samorząd komunalny

Keywords: municipal chancery, parish church, location, town, municipal seal, Magdeburg Law, civic self-government

Pierwszy krytyczny zarys dziejów Sandomierza od czasów najdawniejszych po sobie współczesne przedstawił już historyk i kanonik sandomierski Melchior Buliński (1810-1877)2. Klasyczna monografia, wydana pośmiertnie w 1879 r., stanowi ukoronowanie wieloletniej kwerendy źródłowej autora. O jej doniosłości decyduje zwłaszcza fakt, że znaczna część dokumentacji spożytkowanej przez Bulińskiego nie dochowała się do dziś. Sięgając po tę pracę, trzeba jednak pamiętać, że autorowi zdarzało się pomijać kwestię pochodzenia i wiarygodności przytaczanych przez siebie informacji, przyjmowanych następnie nieraz bezkrytycznie w późniejszej literaturze przedmiotu. Zasadniczy rozwój trwających do dziś badań nad dziejami lokacyjnego Sandomierza nastąpił po 1958 r., kiedy to rozpoczęto systematyczne wykopaliska archeologiczne, zintensyfikowane w 1. 1969-1973. Ich wyniki opublikowano w 1. 1992 i 1996³. Wcześniej już, w 1967 r., ukazał się zbiór studiów historycznych poświęconych dziejom

${ }^{1}$ Niniejszy artykuł jest rozwiniętą wersją referatu wygłoszonego 7 X 2016 r. w Sandomierzu, podczas konferencji upamiętniającej 730. rocznicę lokacji Sandomierza i został złożony do druku za zgodą organizatorów konferencji.

${ }^{2}$ M. B u li ń s k i, Monografia miasta Sandomierza, Warszawa 1879. Zob. J. Wy r zy k o w s k i, Buliński Melchior, w: Polski słownik biograficzny, t. III, Kraków 1937, s. 125.

3 Sandomierz: badania 1969-1973, t. I-II, red. S. Tabaczyński, Warszawa 1992-1996 (Polskie badania archeologiczne 31-32). Zarys historii badań przedstawił S. Ta b a c z y ń ski, Wprowadzenie, w: tamże, t. I, s. 10. Zob. także A. B u k o, Początki Sandomierza, Warszawa 1998. 
ziemi sandomierskiej i Sandomierzowi ${ }^{4}$. Ich autorzy skoncentrowali się głównie na historii osadnictwa w rejonie Sandomierza, statusie administracyjnym miasta i całego regionu oraz ich umiejscowieniu na szlakach handlowych. Od zagadnień tych nie odbiega zasadniczo kwestionariusz zastosowany w Dziejach Sandomierza z 1993 r. ${ }^{5}$ Z punktu widzenia historyka interesującego się dziejami polskich miast lokacyjnych kluczowe znaczenie posiadają zawarte we wspomnianych dziełach studia Tadeusza Lalika. Badacz ten przedstawił aktualną w wielu miejscach do dziś analizę wszystkich znanych sobie źródeł pisanych oświetlających przebieg lokacji Sandomierza w 1286 r., a także historię miasta w okresie poprzedzającym lokację . Obserwacje T. Lalika wpisują się oczywiście w dłuższą tradycję badań nad urbanizacją Małopolski, rozpoczętych przez Józefa Krzyżanowskiego i kontynuowanych głównie przez Antoniego Gąsiorowskiego, Jerzego Lucińskiego, Jerzego Wyrozumskiego, Annę Berdecką i Feliksa Kiryka ${ }^{7}$. W 2005 r. ukazała się monografia Marka Florka, który dokonał podsumowania wyników dotychczasowych badań archeologicznych i historycznych nad średniowiecznym Sandomierzem, a także podjął się ambitnej próby zarysowania całościowego obrazu przeobrażeń przestrzennych prowadzących do przeformowania wczesnośredniowiecznego ośrodka grodowego w dojrzałe miasto lokacyjne, jakie znamy za panowania Kazimierza Wielkiego ${ }^{8}$. Autor, adekwatnie do swojej specjalizacji, skoncentrował się jednak na analizie materiałów archeologicznych, posługując się raczej pomocniczo przekazami pisanymi. Wydaje się więc zrozumiałe, że niektóre jego obserwacje i interpretacje wymagają weryfikacji lub uzupełnienia. Tym mocniej trzeba więc podkreślić wartość rozwijanych w ostatnich latach studiów szczegółowych nad źródłami oświetlającymi lokację miasta. Należy tu zwłaszcza wymienić prace Henryka Seroki dotyczące pieczęci i herbów Sandomierza9

${ }^{4}$ Studia sandomierskie. Materiały do dziejów miasta i regionu sandomierskiego, cz. 1-2, red. T. Wąsowicz, J. Pazdur, Sandomierz 1967.

${ }^{5}$ Dzieje Sandomierza, red. H. Samsonowicz, t. I: Średniowiecze, red. S. Trawkowski, Warszawa 1993.

${ }^{6}$ T. L a li k, Sandomierz w świetle źródeł pisanych, w: Sandomierz: badania (jak w przyp. 3), t. I, s. 49-72; t e n ż e, Lokacja Sandomierza w 1286 roku, w: Dzieje Sandomierza, t. I (jak w przyp. 5), s. 99-114.

${ }^{7}$ J. K r z y ż a n o w s k i, Polityka miejska Bolesława Wstydliwego, w: Studia historyczne ku czci Stanisława Kutrzeby, t. II, Kraków 1938, s. 381-430; A. G ą s i o r o w s k i, Ze studiów nad szerzeniem się tzw. prawa niemieckiego we wsiach ziemi krakowskiej i sandomierskiej (do roku 1333), Roczniki Historyczne 26, 1960, s. 123-170; J. L u c iń s ki, Lokacje wsi i miast monarszych w Małopolsce do 1385 r., Czasopismo Prawno-Historyczne 17, 1965, z. 2, s. 93-122; J. Wy r o z u m s k i, Rozwój sieci miejskiej w Małopolsce w średniowieczu i u progu czasów nowożytnych, Kwartalnik Historii Kultury Materialnej 28, 1980, s. 363-372; A. B e r d e c k a, Lokacje i zagospodarowanie miast królewskich w Małopolsce za Kazimierza Wielkiego (1333-1370), Wrocław 1982; F. K i ry k, Rozwój urbanizacji Małopolski XIII-XVI w. Powiaty południowe, Kraków 1985; t e n ż e, Urbanizacja Małopolski. Województwo sandomierskie: XIII-XVI wiek, Kielce 1994; t e n ż e, Miasta małopolskie w średniowieczu i czasach nowożytnych, Kraków 2013.

${ }^{8}$ M. F l or e k, Sandomierski ośrodek grodowo-miejski w średniowieczu. Przemiany przestrzenne i funkcjonalne, Warszawa 2005.

${ }^{9}$ H. S e roka, Herby miast małopolskich do końca XIII wieku, Warszawa 2002, wg indeksu; t e n ż e, Herby miasta królewskiego Sandomierza, Sandomierz 2016. 
oraz Tomisława Giergiela i Roberta Jopa poświęcone przywilejowi lokacyjnemu z 1286 r. ${ }^{10}$ Warto również wzmiankować opracowane przez F. Kiryka inwentarze dokumentów pergaminowych i rękopisów w archiwum kapituły sandomierskiej ${ }^{11}$. Nie wszystkie koncepcje formułowane w pracach wymienionych badaczy wydają się jednak przekonujące.

Chociaż więc badania nad lokacyjnym Sandomierzem przeżywają w ostatnim czasie wyraźny rozwój, to jednak orientację w stanie wiedzy utrudnia różnorodność przyjmowanych perspektyw i stosowanych metod badawczych. Sytuacja taka prowokuje do podjęcia próby przedstawienia nieco ogólniejszego zarysu dziejów miasta na podstawie bogatych wyników badań analitycznych. Celem niniejszego artykułu będzie również weryfikacja przytaczanych w literaturze informacji o poszczególnych etapach lokacji Sandomierza, a także umiejscowienie tego procesu w szerszym kontekście dziejów miast w Polsce.

Dokonująca się w XIII i XIV w. wszechstronna modernizacja struktur społecznych i ustrojowych na ziemiach polskich przyniosła zasadniczą transformację form życia miejskiego, realizowaną w ramach tzw. kolonizacji na prawie niemieckim ${ }^{12}$. Lokowane miasta, nawet jeśli kontynuowały funkcje gospodarcze i administracyjne wcześniejszych osad targowych, dysponowały w przeciwieństwie do nich własnym prawem i samorządem komunalnym ${ }^{13}$. Zauważalny w ostatnim czasie postęp szczegółowych badań nad procesami lokacyjnymi przekłada się na ogólniejsze zmiany w naszym rozumieniu fenomenu średniowiecznej lokacji miejskiej. Najwcześniejsze etapy kolonizacji postępowały jednak równolegle z procesem umacniania obecności dokumentu w polskiej rzeczywistości prawnej, w związku z czym znalazły dość skromne poświadczenie w źródłach pisanych. Z tego powodu kluczową rolę w badaniach nad miastami lokacyjnymi odgrywają analizy coraz obfitszych materiałów archeologicznych ${ }^{14}$. Kreślony z ich pomocą obraz przeobrażeń towarzyszących lokacjom największych ośrodków miejskich uzmysławia długotrwały charakter tych

${ }_{10}$ T. G i e r g i e 1, R. J o p, Dokument lokacyjny miasta Sandomierza z 1286 roku - forma kancelaryjna, dzieje i edycje, w: T. Giergiel, R. Jop, Dokument lokacyjny Leszka Czarnego dla Sandomierza z 1286 roku, Sandomierz 2015 (Źródła do dziejów Sandomierza 1), s. 17-40.

${ }_{11}$ Pergaminy Archiwum Kapituły Katedralnej Sandomierskiej. Katalog, opr. F. Kiryk, Sandomierz 2002; Inwentarz rękopisów Archiwum Kapituły Kolegiackiej i Katedralnej w Sandomierzu XIII-XX wieku, opr. F. Kiryk, Sandomierz 2010.

12 A. W ę d z k i, Początki reformy miejskiej w Środkowej Europie do połowy XIII wieku, Poznań 1974; B. Z i e n t a r a, Przełom w rozwoju miast środkowoeuropejskich w pierwszej połowie XIII wieku, Przegląd Historyczny 67, 1976, s. 219-243; S. G a w la s, Przełom lokacyjny w dziejach miast środkowoeuropejskich, w: Civitas Posnaniensis. Studia z dziejów średniowiecznego Poznania, Poznań 2005, s. 163-172.

${ }_{13}$ Te n ż e, O kształt zjednoczonego Królestwa. Niemieckie władztwo terytorialne a geneza społeczno-ustrojowej odrębności Polski, wyd. 2, Warszawa 2000, s. 36.

${ }^{14}$ Szczegółowe zreferowanie bogatego dorobku badań archeologicznych nad przestrzenią i kulturą materialną polskich miast lokacyjnych wykracza poza ramy niniejszego artykułu. Zob. J. P i e k a ls ki, Od Kolonii do Krakowa. Przemiana topografii wczesnych miast, Wrocław 1999; t e n ż e, Praga, Wrocław i Kraków. Przestrzeń publiczna i prywatna w czasach średniowiecznego przełomu, Wrocław 2014; M. R ę b k o w s k i, Pierwsze lokacje miast w Księstwie Zachodniopomorskim. Przemiany przestrzenne i kulturowe, Kołobrzeg 2001; Stan badań archeologicznych miast w Polsce, red. H. Paner, M. Fudziński, Z. Borcowski, Gdańsk 2009. 
procesów i skalę towarzyszących im wysiłków organizacyjnych i finansowych ${ }^{15}$. Obserwacje te znajdują uzasadnienie w dość zawiłych dziejach Sandomierza. Uprzedzając dalsze rozważania, podkreślmy, że przedsięwzięcia wpisujące się $\mathrm{w}$ proces lokacyjny trwały długo i postępowały w kilku etapach. Najwcześniejsza osada miejska powstała już w pierwszej ćwierci XIII w. na Wzgórzach Staromiejskich, jednak w drugiej połowie stulecia osadnictwo zostało przeniesione w całości na Wzgórze Miejskie, w sąsiedztwo podgrodzia na Wzgórzu Katedralnym i grodu książęcego na Wzgórzu Zamkowym ${ }^{16}$. Kolejna zasadnicza reforma, stabilizująca struktury przestrzenne, materialne i ustrojowe miasta, nastąpiła z kolei za panowania Kazimierza Wielkiego. Mimo spustoszenia przez Tatarów w XIII w. Sandomierz awansował do grona najbardziej znaczących miast Małopolski, dystansując wcześniej rozwinięty Zawichost ${ }^{17}$. W późnośredniowiecznych źródłach skarbowych zaliczano Sandomierz do miast drugiej kategorii pod względem wielkości ${ }^{18}$. Szacuje się, że w połowie XIV w. mieszkało w nim około 3000 osób $^{19}$, co stanowi około czwartej lub trzeciej części populacji ówczesnego Krakowa (bez przedmieść, Kazimierza i Kleparza) ${ }^{20}$. Szacunki te mają oczywiście orientacyjny charakter, a zachowana dokumentacja źródłowa nie pozwala ocenić nawet przybliżonych skutków demograficznych trzynastowiecznych najazdów tatarskich.

Najstarszym przekazem źródłowym informującym wprost o lokacji Sandomierza jest dopiero przywilej lokacyjny, wystawiony w 1286 r. przez księcia Leszka Czarnego ${ }^{21}$. W dokumencie tym można jednak wskazać poszlakę świadczącą o tym, że pierwsze wysiłki kolonizacyjne podjęto jeszcze w pierwszej połowie XIII w. Mianowicie w jednej z formuł końcowych dyplomu unieważniono starsze, bliżej nieokreślone przywileje super predicta civitate, wystawione jeszcze przez Bolesława Wstydliwego vel ab antecessore ipsius, a więc prawdopodobnie Leszka Białego. Za koncepcją wiążącą początki lokacji Sandomierza z tym księciem przemawia także wzmianka w dokumencie Bolesława Wstydliwego z 1260 r., zatwierdzającym uposażenie cystersów wąchockich. Jest to co prawda falsyfikat, opierał się on jednak

15 Ostatnio: S. G a w l a s, Ustrojowe i społeczne uwarunkowania lokacji miejskich na ziemiach polskich w 1. połowie XIII wieku, Archaeologia Historica Polona 23, 2015, s. 7-56.

${ }_{16}$ A. B u k o, Warunki naturalne Sandomierza i elementy pierwotnej rzeźby terenu, w: Sandomierz: badania (jak w przyp. 3), t. I, s. 19-48; M. F l o r e k, Sandomierski ośrodek, s. 8-13.

${ }^{17}$ A. Te t e r y c z - P u z i o, Geneza województwa sandomierskiego. Terytorium i miejsce w strukturze państwa polskiego w średniowieczu, Słupsk 2001, s. 167 n.

${ }_{18}$ Z. Kulejewska-Topolska, Oznaczenia i klasyfikacje miast w dawnej Polsce (XVI-XVIII w.), Czasopismo Prawno-Historyczne 8, 1956, z. 2, s. 262 n.; H. S a m s o n o w i c z, M. B o g u c k a, Dzieje miast i mieszczaństwa w Polsce przedrozbiorowej, Wrocław 1986, s. 117.

${ }^{19}$ F. K i r y k, Urbanizacja Małopolski, s. 125. Zob. także Z. Guld o n, Terytorium, zabudowa i zaludnienie, w: Dzieje Sandomierza, t. II, cz. 2, Warszawa 1993, s. 26.

${ }^{20}$ J. W y r o z u m s k i, Kraków do schyłku wieków średnich, Kraków 1992 (Dzieje Krakowa, t. I), s. 314-317.

${ }^{21} \mathrm{~W} 1858$ r. dokument wydano na podstawie osiemnastowiecznego odpisu z materiałów A. Naruszewicza: Codex diplomaticus Poloniae, t. I-III, wyd. L. Ryszczewski, A. Muczkowski, Warszawa 1847-1858 (dalej cyt.: CDP), tu t. III, nr 63. Zob. L. S tę p k o w s k i, Biskup Adam Naruszewicz o chronologii przywileju lokacji Sandomierza z 1286 roku, Zeszyty Sandomierskie 18, 2004, s. 21-23; T. G i e r g i e 1, R. J o p, Dokument, s. 17-40 (tamże, s. 45-53, edycja na podstawie oryginału). 
przypuszczalnie się na starszych zapisach. Wynika z niego, że przed rokiem 1243 cystersi nabyli za 40 grzywien srebra dział ziemi koło Sandomierza, należący do Piotra syna sołtysa oraz Jana i Stefana synów Lamberta ${ }^{22}$. Niewymieniony z imienia ojciec Piotra był prawdopodobnie sołtysem gminy niemieckich kupców w Sandomierzu ${ }^{23}$. Organizacja obdarzonej immunitetem prawnym gminy kupieckiej od dawna jest uważana za najwcześniejszy etap przełomu lokacyjnego dużych polskich miast w XIII w. ${ }^{24}$ Dopiero następnym krokiem była zwykle całkowita reforma stosunków własnościowych i ustrojowych, która prowadziła do powstania organizmu miejskiego rządzącego się własnym prawem. W Małopolsce proces ten znajduje najlepsze oświetlenie w źródłach dokumentujących lokację Krakowa - kupcy niemieccy z sołtysem pojawili się tam przed 1228 r., a więc jeszcze za rządów Leszka Białego, jednak prawne i przestrzenne podstawy rozwoju miasta komunalnego uformował dopiero jego następca, Bolesław Wstydliwy, na etapie wielkiej lokacji z 1257 r. ${ }^{25}$

Poszczególne etapy rozwoju osadnictwa miejskiego w Sandomierzu przed lokacją z 1286 r. dają się zaobserwować przede wszystkim z perspektywy przekazów oświetlających proces kształtowania struktur kościelnych miasta. Szczególnie charakterystycznym, powtarzalnym momentem organizacji kościelnej dużych miast lokacyjnych w pierwszej połowie XIII w. było sprowadzenie dominikanów i osadzenie ich przy dotychczasowym kościele parafialnym, a następnie przeniesienie siedziby parafii do kościoła położonego bliżej centrum rozwijającego się osadnictwa miejskiego. Towarzyszyło temu na ogół sprowadzenie franciszkanów i ufundowanie szpitala $^{26}$. Za sprawą starań biskupa Iwona Odrowąża - odpowiedzialnego wcześniej za sprowadzenie dominikanów do Krakowa i ufundowanie przyszłej fary miejskiej - konwent taki osiadł w 1226 r. również na Wzgórzach Staromiejskich w Sandomierzu, przy kościele św. Jakuba ${ }^{27}$. Datę taką wskazują IV i V redakcja Katalogu

${ }^{22}$ Zbiór dokumentów małopolskich, cz. IV, wyd. S. Kuraś, Wrocław 1962, nr 875.

23 T. L a li k, Sandomierz, s. 61-62.

${ }^{24}$ A. Rutkowska-Płach cińs ka, Gmina miejska w początkach XIII w. w Polsce, w: Wieki średnie - medium aevum. Prace ofiarowane Tadeuszowi Manteufflowi w 60. rocznicę urodzin, Warszawa 1962, s. 143-150; B. Z i e n t a r a, Przemiany społeczno-gospodarcze i przestrzenne miast w dobie lokacji, w: Miasta doby feudalnej w Europie Środkowo-Wschodniej. Przemiany społeczne a układy przestrzenne, Warszawa 1976, s. 67-97; t e n ż e, Przełom, s. 219-241; S. G a w la s, Ustrojowe i społeczne uwarunkowania, s. 7-56.

${ }_{25}$ J. R a j m a n, Krakowska civitas sołtysów Piotra i Salomona, w: Społeczeństwo Polski średniowiecznej, t. XII, Warszawa 2012, s. 47-68.

${ }^{26}$ M. S ło ń, Fundatio civitatis. Program fundacyjny procesu lokacyjnego na przykładzie Wrocławia, Krakowa i Poznania, w: Procesy lokacyjne miast w Europie Środkowo-Wschodniej, Wrocław 2006, s. 227-245.

27 Z. G oł u b i e w o w a, Kościół dominikański pw. św. Jakuba w Sandomierzu w XIII stuleciu i jego dekoracja architektoniczna, w: Studia nad historią dominikanów w Polsce 12221972, t. II, Warszawa 1975, s. 42 n.; T. L a 1 i k, Sandomierz, s. 61; A. B u k o, Sandomierz wczesnopiastowski, w: Dzieje Sandomierza, t. I (jak w przyp. 5), s. 74-75; t e n ż e, Najstarsze kościoły dominikańskie w przestrzeni ośrodków wczesnomiejskich na ziemiach polskich, w: Dominikanie. Gdańsk - Polska - Europa, Gdańsk-Pelplin 2003, s. 290-293; M. F 1 o r e k, Sandomierski ośrodek, s. 35; t e nże, Kościół św. Jakuba i dawny klasztor dominikanów w Sandomierzu. Wyniki badań archeologiczno-architektonicznych, Kwartalnik Historii Kultury Materialnej 42, 1994, s. 3-25. 
biskupów krakowskich ${ }^{28}$ oraz Jan Długosz ${ }^{29}$. Ten ostatni dodał, że sprowadzeniu dominikanów towarzyszyła fundacja kościoła św. Pawła, dokąd przeniesiono siedzibę parafii z kościoła św. Jakuba ${ }^{30}$. Pierwsze próby stworzenia miasta lokacyjnego w Sandomierzu skoncentrowały się więc najwyraźniej na Wzgórzach Staromiejskich, położonych szczególnie dogodnie na starym trakcie handlowym w kierunku Rusi ${ }^{31}$. Przypuszcza się, że życie kupieckie i wczesna zabudowa miejska koncentrowały się wzdłuż dzisiejszej ulicy Staromiejskiej, pełniącej funkcję ulicy targowej łączącej dawną i nową farę, kościoły św. Jakuba i św. Pawła ${ }^{32}$. Przejawem zainteresowania miastem ze strony następcy Leszka, Bolesława Wstydliwego, oraz jego siostry Salomei było ufundowanie konwentu franciszkańskiego, do czego doszło krótko przed $1243 \mathrm{r}^{33}$ W 1245 r. odbyła się tu nawet kapituła prowincjonalna, w trakcie której Salomea wstąpiła do klasztoru klarysek ${ }^{34}$. Wkrótce jednak sandomierscy franciszkanie zostali przeniesieni do Zawichostu, gdzie mieli prowadzić szpital przy nowo ufundowanym klasztorze klarysek ${ }^{35}$.

${ }^{28}$ Katalogi biskupów krakowskich, wyd. J. Szymański, Warszawa 1974, Monumenta Poloniae historica, series nova, t. X, cz. 2, s. 60, 92.

${ }^{29}$ Ioannis Dlugossii Annales seu cronicae incliti Regni Poloniae (dalej cyt.: Annales), lib. V-VI, Warszawa 1964, s. 246; Joannis Długosz, Liber beneficiorum dioecesis Cracoviensis (dalej cyt.: LB), wyd. A. Przeździecki, t. I-III (= Opera omnia, t. VII-IX), Kraków 1863-1864, tu t. III, s. 454-455. Dacie wskazanej przez te źródła nie przeczy również miejsce, pod którym wymieniono sandomierski konwent na liście klasztorów polskiej prowincji dominikańskiej, sporządzonej w 1304 r. przez Bernarda Guidonis (J. Kło c z ow s ki, Dominikanie polscy na Śląsku w XIII-XIV wieku, Lublin 1956, s. 292).

${ }^{30}$ LB III, s. 454-455: Sandomiriense monasterium ordinis praedicatorum, habet duo loca eiusdem ordinis praedicatorum, unum in antiqua civitate Sandomiriensi extra muros, quod Yvo Cracoviensis episcopus anno Domini 1226 ecclesia parochiali Sancti Jacobi totius antiquae civitatis demolita et extincta, et ecclesia Sancti Pauli pro parochia fundata et erecta, atque sufficienter dotata, fundat, erigit et creat, et fratribus ordinis praedicatorum consignat. Por. Annales, lib. V-VI, s. 246. Zob. Z. M or a w s k i, Wspólnoty parafialne późnośredniowiecznego Sandomierza, w: Studia nad dziejami miast i mieszczaństwa w średniowieczu, Toruń 1996, s. 157.

${ }^{31}$ T. W ą s o w i c z, Sandomierska sieć drożna w wiekach średnich, w: Studia sandomierskie (jak w przyp. 4), s. 116-119; A. B u k o, Wzgórza Staromiejskie, w: Sandomierz: badania, t. I (jak w przyp. 3), s. 285.

${ }^{32}$ T. L a 1 i k, Sandomierz, s. 62; A. B u k o, Początki, s. 112; M. F 1 o r e k, Sandomierski ośrodek, s. 36. Szerzej S. G a w l a s, Ulica a zmiany krajobrazu miejskiego w okresie lokacji, Kwartalnik Historii Kultury Materialnej 47, 1999, z. 1-2, s. 18-23.

${ }^{33} \mathrm{~W}$ tym roku konwent przyjęto do zakonu na kapitule generalnej w Złotoryi (G. L a b u d a, Franciszkanie polscy w źródłach narracyjnych prowincji polsko-czeskiej w średniowieczu, w: Zakony franciszkańskie w Polsce, t. I, cz. 2-3, Lublin 1983, s. 17; D. K a r c z e w s k i, Franciszkanie w monarchii Piastów i Jagiellonów w średniowieczu. Powstanie - rozwój organizacja wewnętrzna, Kraków 2012, s. 50).

${ }^{34}$ Rocznik małopolski, wyd. A. Bielowski, Monumenta Poloniae historica, t. III, Lwów 1878 , s. $168,169$.

35 T. L a li k, Zawichost we wcześniejszym średniowieczu, Kwartalnik Historii Kultury Materialnej 40, 1992, z. 2, s. 148; F. K i r y k, Urbanizacja Małopolski, s. 164-166; P. P e n c a k o w s k i, Sanktuaria minoryckie w Zawichoście i Nowym Korczynie. Dwie fundacje związane z księciem Bolesławem Wstydliwym i jego rodziną, Kwartalnik Architektury i Urbanistyki 37, 1992, z. 2, s. 119-143; A. P l e s z c z y ń s k i, Podłoże polityczne i ideowe 
Rozwój osadnictwa na Wzgórzach Staromiejskich w Sandomierzu został zahamowany przez drugi najazd tatarski w 1259-1260 r. Najeźdźcy mieli podobno wymordować ludność miasta, również dominikanów z klasztoru św. Jakuba ${ }^{36}$. Bolesław Wstydliwy nie podjął bardziej zdecydowanych kroków ku odbudowie Sandomierza. Wypomniał mu to potem Leszek Czarny w wystawionym przez siebie w 1286 r. przywileju lokacyjnym. Dokument ten inaugurował nowy etap w procesie formowania ośrodka miejskiego ${ }^{37}$. Operacja osadnicza polegała tym razem na całkowitym przeniesieniu dawnego miasta na Wzgórze Miejskie, graniczące od południa ze Wzgórzem Katedralnym, z podgrodziem i kolegiatą NMP, a więc ad montem circa ecclesiam s. Mariae, jak to później opisano w dokumencie książęcym dla dominikanów z 1286 r. ${ }^{38}$ Wysoko wyniesione, rozległe Wzgórze Miejskie ograniczone było od zachodu wąwozami, a od wschodu - doliną Wisły, leżało jednak w pewnym oddaleniu od przeprawy przez Wisłę i traktu handlowego przebiegającego przez Wzgórza Staromiejskie ${ }^{39}$. Można przypuszczać, że, obok względów własnościowych, duży wpływ na wybór miejsca pod lokację miały potrzeby natury obronnej. Gdy w 1286 r. książę przekazywał dominikanom działkę na terenie przyszłego miasta lokacyjnego, wyraził zamiar zapewnienia im schronienia przed przyszłymi najazdami $^{40}$. Podobnymi przesłankami kierował się również w 1287 r., przenosząc Nową Brzeźnicę ad locum, in quo apcius et comodius vallo municionis firmarii possit ${ }^{41}$. Przenosiny ośrodka miejskiego musiały też pociągnąć za sobą zmiany majątkowe,

fundacji Bolesława Wstydliwego dla zakonu klarysek w Zawichoście, w: Peregrinatio ad veritatem. Studia ofiarowane profesor Aleksandrze Witkowskiej OSU z okazji 40-lecia pracy naukowej, Lublin 2004, s. 381-392; t e n ż e, Fundacja opactwa klarysek w Zawichoście w 1245 roku a aspiracje polityczne Bolesława Wstydliwego, w: Klasztor w państwie średniowiecznym i nowożytnym, Wrocław 2005, s. 177-192.

${ }^{36}$ R. Ś w i ęt o c h o w s k i OP, Sadok i 58 męczenników sandomierskich, w: Hagiografia polska. Słownik bio-bibliograficzny, t. II, Poznań 1972, s. 286; T. L a 1 i k, Sandomierz, s. 63-64; K. S t o p k a, Męczennicy sandomierscy. Legenda i rzeczywistość, Nasza Przeszłość 80, 1993, s. 55-58; T. G i e r g i e 1, O męczennikach dominikańskich i sandomierskich podczas najazdu tatarskiego na Sandomierz na przełomie lat 1259 i 1260 oraz o ich kulcie, w: Relikwią ziemi jest w nim... O męczennikach dominikańskich i sandomierskich podczas najazdu tatarskiego na Sandomierz na przełomie lat 1259 i 1260 oraz o ich kulcie, Sandomierz 2016, s. 7-44. Zob. także A. R u t k o w s k a - P ł a c h c i ń s k a, Podanie o Piotrze z Krępy w świetle rękopisów Rocznika świętokrzyskiego nowego oraz późniejszych przekazów, w: Mente et litteris. O kulturze i społeczeństwie wieków średnich, Poznań 1984, s. 263-270; t a ż, Sprawy tatarskie w Roczniku tak zwanym świętokrzyskim nowym: podkład źródłowy i warstwa anegdotyczna, Studia Źródłoznawcze 30, 1987, s. 64.

37 T. L a lik, Lokacja Sandomierza w 1286 roku, w: Dzieje Sandomierza, t. I (jak w przyp. 5), s. 99-114.

38 Z. M a z u r, Dwa dokumenty Leszka Czarnego dla dominikanów sandomierskich, Studia Historyczne 12, 1969, s. 607; A. B u k o, Warunki naturalne, s. 41-44; t e n ż e, Sandomierz wczesnopiastowski, w: Dzieje Sandomierza, t. I (jak w przyp. 5), s. 80-90.

39 T. W ą s o w i c z, Sandomierska sieć drożna, s. 118.

${ }^{40}$ Z. M a zur, Dwa dokumenty, s. 608: etiam ne insultus Tartarorum aut quorumlibet aliorum praedictos fratres oporteat deinceps formidare, aut in rebus domus, vel ipsa domo difficili modo conquisita et comparata damnificare.

${ }^{41}$ CDP I, nr 67. 
które uderzyły zwłaszcza we własność kościelną ${ }^{42}$. Z dokumentu immunitetowego z 1284 r. wynika, że do uposażenia kolegiaty należały w tym czasie dwa źrebia circa civitatem Sandomiriensem ${ }^{43}$, w samym zaś przywileju lokacyjnym wzmiankowano trzy karczmy, z których jedna należała do biskupa, a dwie - do kolegiaty. W 1292 r. Władysław Łokietek włączył do prebendy kustodii kapituły sandomierskiej cztery źrebia we wsi Piekary, rekompensując kustoszowi Zygfrydowi konfiskatę wsi Sokolniki, która została wcielona do uposażenia miasta Sandomierza przez Leszka Czarnego ${ }^{44}$. Prawdopodobnie z tego powodu około $1286 \mathrm{r}$. Zygfryd ustąpił z podkanclerstwa ${ }^{45}$. Z kolei klaryski krakowskie pamiętały w XV w., że w związku z lokacją Sandomierza odebrano im wieś Kobierniki ${ }^{46}$.

Całkowita translokacja miasta uzmysławia skalę aspiracji politycznych Leszka, który po stłumieniu buntu możnych w 1285 r. starał się wykreować nowy punkt oparcia władzy książęcej w ziemi sandomierskiej ${ }^{47}$. Poszczególne postanowienia przywileju lokacyjnego świadczą o ambitnym planie przekształcenia Sandomierza w znaczący ośrodek handlu dalekosiężnego, rzemiosła i rynku lokalnego. Jako pierwsze miasto w Małopolsce Sandomierz otrzymał całkowite prawo składu. Leszek nadał też, zastosowane po raz pierwszy w księstwie, prawo mili miejskiej, które obowiązywało w odniesieniu do karczem, z wyjątkiem jednej karczmy biskupiej i dwóch kolegiackich. Zgodził się, żeby mieszczanie bili własną monetę denarową, choć pod książęcym stemplem i według wartości monety publicznej ${ }^{48}$. Zezwolił na organizowanie dwutygodniowego jarmarku w dzień Wniebowstąpienia patronki kolegiaty. Przeprowadzenie lokacji powierzono mieszczaninowi krakowskiemu Witkowi, pełniącemu funkcję książęcego żupnika ${ }^{49}$. Przedsięwzięcie zakładało wytyczenie szachownicowo-blokowego układu zabudowy z czworobocznym rynkiem ${ }^{50}$. Prawdopodobnie

${ }^{42}$ T. L a 1 i k, Sandomierz, s. 69.

${ }^{43}$ Kodeks dyplomatyczny Małopolski, t. I-IV, wyd. F. Piekosiński, Kraków 1876-1905 (dalej cyt.: KDM), tu t. I, nr 104.

${ }^{44} \mathrm{KDM}$ I, nr 120.

45 Z. M a zu r, Studia nad kancelarią księcia Leszka Czarnego, Wrocław 1975, s. 173174. W 1303 r. Zygfryd ufundował wraz z kapitułą sandomierską, przy wsparciu biskupa Jana Muskaty, kanonię zwaną subkustodią, którą uposażył polami w Makoszynie i Piekarach i domem obok kustodii (KDM I, nr 133; LB III, s. 374). Wkrótce jednak zginął jako zwolennik Władysława Łokietka z rąk najemników Muskaty (T. P i e tr a s, „Krwawy wilk z pastorałem”. Biskup krakowski Jan zwany Muskatą, Warszawa 2001, wg indeksu; L. P o n i e w o z i k, Prałaci i kanonicy sandomierscy w okresie średniowiecza, Toruń 2004, s. 342-343).

46 LB III, s. 319.

${ }^{47}$ P. K. W o j c i e c h o w s k i, Ugrupowania polityczne w ziemiach krakowskiej i sandomierskiej w latach 1280-1286, Przegląd Historyczny 70, 1979, s. 57-72; T. L a 1 i k, Lokacja, s. 100-102; P. Ż m u d z k i, Studium podzielonego Królestwa. Książę Leszek Czarny, Warszawa 2000, s. 399 n.

${ }^{48}$ B. P a s z k i e w i c z, Kraków, Sandomierz i mennictwo Władysława Łokietka, w: Miasta, ludzie, instytucje, znaki. Księga jubileuszowa ofiarowana Profesor Bożenie Wyrozumskiej w 75. rocznicę urodzin, Kraków 2008, s. 765-788.

49 J. P t a ś n i k, Studia nad patrycjatem krakowskim wieków średnich, cz. 1, Rocznik Krakowski 15, 1913, s. 35.

${ }^{50}$ B. Kras now olski, Lokacyjne układy urbanistyczne na obszarze ziemi krakowskiej w XIII i XIV wieku, cz. 2, Kraków 2004, s. 196-206; t e nże, Układ urbanistyczny lokacyjnego Sandomierza (1286) - analiza modularna, w: Atlas historyczny miast polskich, 
równocześnie przystąpiono do wznoszenia wałów drewniano-ziemnych, które wzmiankowano w innym dokumencie książęcym z $1286 \mathrm{r} \cdot{ }^{51} \mathrm{Na}$ uposażenie ziemskie miasta miało złożyć się aż 220 łanów frankońskich. Co szósty łan powinien należeć do wójtów, którym nadano oprócz tego jeszcze osiem łanów. W całej dotychczasowej literaturze przyjmowano jednak, że w realizacji tego ambitnego planu osadniczego przeszkodziła śmierć władcy i późniejszy zamęt polityczny w Małopolsce ${ }^{52}$. Uważa się, że w ostateczności miasto zajęło mniejsze uposażenie, oceniane na niecałe 93 łany chełmińskie $^{53}$. Tak rzeczywiście obszar miejski został opisany w lustracji dóbr królewskich z 1564/1565 54 Jednak ,pytani o defekt tych łanów” mieszczanie odpowiedzieli wtedy, że zostały one zagarnięte pod folwarki. Możliwe zatem, że pierwotne, trzynastowieczne uposażenie miejskie było większe, a malało dopiero z czasem. Nie można również wykluczyć, że uległo ono pomniejszeniu po stłumieniu buntu przeciwko księciu w 1312 r. Nic natomiast nie wiadomo o egzekwowaniu przez mieszczan sandomierskich prawa składu. Wydaje się wątpliwe, by próby takie spotkały się z akceptacją Krakowa.

Lokacji na Wzgórzu Miejskim w 1286 r. musiała towarzyszyć przynajmniej częściowa reorganizacja struktur kościelnych. Już w dokumencie lokacyjnym Leszek Czarny pozwolił na erygowanie osobnej parafii dla mieszczan (parochia specialis), zastrzegając, że uzyskał na to zgodę biskupa. Rola głównej świątyni parafialnej lokacyjnego Sandomierza przypadła kościołowi św. Piotra na Wzgórzu Gostomianum. W czasie bliskim lokacji władca przekazał konwentowi dominikanów działkę w obrębie obwałowań miejskich, limitatam et signis notabilibus assignatam pro domo construenda et habenda ${ }^{55}$. Około połowy XIV w. na działce stanął klasztor z kościołem św. Marii Magdaleny, a użytkujący go konwent znajdował się pod stałym

t. V, z. 2, Sandomierz-Kraków 2014, s. 8; M. F 1 o r e k, Sandomierski ośrodek, s. 43. Por. W. Kalinowski, T. Lalik, T. Przypkowski, H. Rutkowski, S. Trawkowski, Sandomierz, Warszawa 1956, s. 24 n.; Z. M o r a w s k i, Sandomierz od końca XIII do początków XV wieku, w: Dzieje Sandomierza, t. I (jak w przyp. 5), s. 127.

51 Z. M a z u r, Dwa dokumenty, s. 608: aream in munitione eiusdem civitatis limitatam et signis notabilibus assignatam pro domo construenda et habenda. O przystąpieniu do budowy obwarowań informuje też czternastowieczna Kronika katedralna krakowska (fragment wydany jako Rocznik kujawski, Monumenta Poloniae historica, t. III, s. 207). Z próbą przesunięcia datowania obwarowań dopiero na okres około 1321 r. wystąpił M. F l o r e k, Najstarsze fortyfikacje miejskie Sandomierza w świetle ostatnich odkryć archeologicznych, Sprawozdania Archeologiczne 55, 2003, s. 211-230; t e n ż e, Sandomierski ośrodek, s. 44-46. Bazuje on jednak wyłącznie na pięciu dendrodatach (1303, 1312, 1315 i dwukrotnie 1321), które uzyskano w toku analizy reliktów obwarowań odkrytych w 2001 r. na ul. Żydowskiej. W świetle zestawionych źródeł trudno przyjąć tę hipotezę. Wzmianka w dokumencie książęcym z $1286 \mathrm{r}$. świadczy przynajmniej o przystąpieniu do wznoszenia obwarowań jeszcze na etapie lokacji, nie można zresztą wykluczyć możliwości przebudowy obwarowań w czasach pierwszych udokumentowanych prac na grodzie sandomierskim około 1328 r., zob. niżej, przyp. 78.

52 T. L a li k, Sandomierz w świetle źródeł pisanych, s. 69.

53 Te n ż e, Lokacja, s. 104.

${ }^{54}$ Lustracja dóbr królewskich województwa sandomierskiego 1564-1565, wyd. W. Ochmański, Wrocław 1963, s. 82-83. H. R u t k o w s k i, Z dziejów Sandomierza w okresie Odrodzenia, w: Studia sandomierskie (jak w przyp. 4), s. 291; F. Kiryk, Rolnictwo, w: Dzieje Sandomierza, t. II, cz. 1, Warszawa 1993, s. 185.

${ }_{55}$ Z. M a z u r, Dwa dokumenty, s. 608. 
zwierzchnictwem starszego klasztoru św. Jakuba na Wzgórzach Staromiejskich ${ }^{56}$. Prawdopodobnie $\mathrm{w}$ trosce o stan miejskiego majątku, a zapewne też swe własne dochody z miasta, książę uregulował stosunki finansowe dominikanów z mieszczanami - w przywileju lokacyjnym zabronił zakonnikom sprzedaży ryb łowionych w Wiśle, a w innym dokumencie z tego roku zarządził, by zamiast zapisywanych klasztorowi przez mieszczan nieruchomości wypłacane były ekwiwalenty pieniężne przez „wójta lub mieszczan” ( $a b$ advocato vel civibus Sandomiriensibus), chyba że uzyskaliby na to zgodę księcia, wójta i wspólnoty mieszczan (consensus domini ducis, advocati et civium universorum civitatis supradictae) ${ }^{57}$. Lokalizację świątyni parafialnej poza obszarem objętym lokacją trzeba oczywiście uznać za nietypową. Wynikała prawdopodobnie z konieczności dostosowania sieci parafialnej nowo powstałego miasta do wcześniejszych stosunków kościelnych. Z kolei peryferyjne umiejscowienie działki dominikańskiej, którą wytyczono w sąsiedztwie wału, nawiązywało do ówczesnych standardów lokalizacji konwentów mendykanckich w przestrzeni miejskiej. Podobnie trzeba ocenić peryferyjne położenie szpitala Świętego Ducha, ufundowanego w 1302 r. przez kasztelana krakowskiego Żegotę na północ od miasta, w rejonie późniejszej Bramy Opatowskiej ${ }^{58}$. Kościół św. Pawła pozostał farą dla przedmieścia krakowskiego, zajmującego tereny dawnego starego miasta. W rachunkach świętopietrza za lata 1325-1327 został określony jako leżący in preurbio civitatis Sandomiriensis ${ }^{59}$. W tych samych rachunkach wzmiankowano kościół św. Wojciecha, efemeryczną farę przedmieścia opatowsko-zawichojskiego, znajdującego się na północ od miasta ${ }^{60}$. Hierarchia kościołów św. św. Piotra, Pawła i Wojciecha znajduje odbicie $w$ ich dochodach, otaksowanych w 1. 1325-1327 na odpowiednio 45, 7 i 4 grzywny ${ }^{61}$. Majątek głównej fary był więc porównywalny z dochodami

${ }^{56}$ W. G 1 i ń s k i, Dominikański kościół św. Marii Magdaleny w Sandomierzu w świetle badań archeologicznych, w: Klasztor w mieście średniowiecznym i nowożytnym, Wrocław-Opole 2006, s. 547-558; D. B u r d z y, Sandomierski klasztor św. Marii Magdaleny w średniowieczu, Nasza Przeszłość 108, 2007, s. 219-224.

57 Z. M a z u r, Dwa dokumenty, s. 608.

${ }^{58}$ KDM II, nr 520. K. A n t o s i e w i c z, Szpital i kościół Św. Ducha w Sandomierzu, Studia Sandomierskie 2, 1981, s. 265-274; M. S t a r n a w s k a, Między Jerozolimą a Łukowem. Zakony krzyżowe na ziemiach polskich w średniowieczu, Warszawa 1999, s. 133-135. W sprawie emendacji daty wystawienia dokumentu zob. Urzędnicy małopolscy XII-XV wieku. Spisy, Wrocław 1990, nr 128; J. K u r t y k a, Elita małopolska XIII i XIV w. - przerwa czy kontynuacja (na przykładzie Toporów: potomstwo Żegoty wojewody i kasztelana krakowskiego), w: Genealogia - polska elita polityczna w wiekach średnich na tle porównawczym, Toruń 1993, s. 46-48; T. N o w a k o w s k i, Małopolska elita władzy wobec rywalizacji o tron krakowski w latach 1288-1306, Bydgoszcz 1992, s. 65-70.

59 Monumenta Poloniae Vaticana, t. III, wyd. J. Ptaśnik, Kraków 1914, nr 139, s. 166. F. K i r y k, Kościół i parafia św. Pawła w Sandomierzu w okresie staropolskim, w: Ecclesia - cultura - potestas. Studia z dziejów kultury i społeczeństwa. Księga ofiarowana Siostrze Profesor Urszuli Borkowskiej OSU, Kraków 2006, s. 105-107.

${ }^{60}$ M. D e r w i c h, Benedyktyński klasztor św. Krzyża na Łysej Górze w średniowieczu, Warszawa-Wrocław 1992, s. 300-301; T. L a 1 i k, Sandomierz, s. 57-58; M. F 1 o r e k, Sandomierski ośrodek, s. 48.

${ }^{61}$ Monumenta Poloniae Vaticana, t. I, wyd. J. Ptaśnik, Kraków 1913, nr 139, s. 162, 166. Zob. E. M a s c h ke, Der Peterspfennig in Polen und dem deutschen Osten, wyd. 2, Sigmaringen 1979, s. $235 \mathrm{n}$. 
dwóch spośród czterech kościołów parafialnych leżących w obrębie murów Krakowa: Świętego Krzyża (45 grzywien) i Wszystkich Świętych (44 grzywny). Dochody sandomierskiego kościoła św. Piotra były wyraźnie wyższe od przysługujących krakowskiemu kościołowi św. Szczepana (21 grzywien i 6 skojców), choć jednocześnie prawie trzykrotnie niższe od dochodów najważniejszej krakowskiej fary, kościoła Mariackiego (133 grzywy) ${ }^{62}$.

Szczególne względy Leszka Czarnego wobec Sandomierza znalazły również wyraz w przepisach regulujących sytuację prawnoustrojową miasta. W przywileju lokacyjnym książę zezwolił mieszczanom na organizowanie sądów bożych pod swą nieobecność i obiecał, że nie ustanowi nad nimi landwójta. Sądy wielkie miały odbywać się trzy razy do roku, a powinien im przewodzić wierny księciu rycerz lub mieszczanin. Zasady wewnętrznego porządku sądowego i ustrojowego w Sandomierzu określało zaprowadzone przez Leszka Czarnego prawo magdeburskie, stosowane w większych miastach Małopolski od czasów lokacji Krakowa w 1257 r. ${ }^{63}$ Umożliwiało ono powołanie zalążków samorządu komunalnego w postaci rady miejskiej, której działalność była warunkiem emancypacji politycznej miasta ${ }^{64}$. Nieprzypadkowo więc może pierwszy przekaz świadczący o traktowaniu mieszczan sandomierskich jako podmiotu prawnego pochodzi właśnie z czasu rządów Leszka, który nadając w 1286 r. dominikanom działkę, powołał się na zgodę wójta i wspólnoty mieszczan. Sandomierską radę miejską wzmiankowano jednak po raz pierwszy dopiero w $1306 \mathrm{r}^{65}$

Niektórzy badacze przypuszczają, że już w związku z lokacją z 1286 r. do użytku kancelaryjnego wprowadzono pierwszą pieczęć miejską ${ }^{66}$. Hipoteza ta wspiera się jednak na niepewnych przesłankach. Jedyny znany odcisk pieczęci Sandomierza miał posłużyć jako contrasigillum pieczęci Leszka Czarnego przy przywileju lokacyjnym z 1286 r. Wiedzę o jej wyglądzie czerpiemy jednak ze znacznie późniejszych przekazów ikonograficznych. Odrys, powstały u schyłku XVIII lub w pierwszej połowie XIX w., znajduje się w kopiarzu przywilejów miejskich w archiwum kapitulnym ${ }^{67}$. Pieczęć ma tu kształt ostroowalny i przedstawia tronującego władcę. Pozostawienie

${ }^{62}$ Monumenta Poloniae Vaticana, t. I, nr 139, s. 113-114. Zob. A. N i e w i ń s k i, Przestrzeń kościelna w topografii średniowiecznego Krakowa. Próba syntezy, Lublin 2004, s. 85-104; J. R a j m a n, Kraków. Zespół osadniczy, proces lokacji i mieszczanie do roku 1333, Kraków 2004, s. 204.

${ }_{63}$ S. E s tr e i c h e r, Kraków i Magdeburg w przywileju fundacyjnym krakowskim, w: Ku uczczeniu Bolesława Ulanowskiego, Kraków 1911, s. 403-435; Studien zur Geschichte des sächsisch-magdeburgischen Rechts in Deutschland und Polen, red. D. Willoweit, W. Schich, Frankfurt a.M. 1980 (Rechtshistorische Reihe 10); K. K a m iń s k a, Lokacje na prawie magdeburskim na ziemiach polskich do 1370 r. Studium historycznoprawne, Toruń 1990; S. G a w la s, O kształt, s. 35-36; Europejskie miasta prawa magdeburskiego. Tradycja, dziedzictwo, identyfikacja, Kraków 2007.

${ }^{64}$ S. G a w l a s, O kształt, s. 36.

${ }^{65}$ Z. M a z u r, Dwa dokumenty, s. 608: consensu - - nostri fidelis advocati Vithconis et civium universorum praedictorum Sandomiriensium; Monumenta Poloniae Vaticana, t. III, nr 121, s. 82.

${ }^{66}$ M. G u m o w s k i, Najstarsze pieczęcie miast polskich XIII i XIV wieku, Toruń 1960, s. 192. Do koncepcji tej powrócił H. S e ro k a, Herby miast małopolskich, s. 22; te nże, Herby miasta królewskiego Sandomierza, s. 8-10.

${ }^{67}$ T. Gi ergi e 1, R. J o p, Dokument, s. 27. 
pustego otoku pozwala przypuszczać, że oryginalny odcisk był już nieczytelny. Kolejne odwzorowanie znajduje się w pracy M. Balińskiego i T. Lipińskiego z $1844 \mathrm{r}^{68}$ Tym razem na ostroowalnej pieczęci przedstawiono dwie postacie pod gotyckim łukiem. Pierwsza, w koronie, klęczy w geście modlitewnym, a druga udziela jej błogosławieństwa. Legenda w otoku brzmi: S(igillum) CIVITATIS S(a)NDOM(irie). Przedstawienie to zostało powielone na rysunku w materiałach W. Wittyga w Muzeum Narodowym w Krakowie ${ }^{69}$. W nowszych badaniach wysunięto hipotezę, że rysunki te ukazują w istocie słabo czytelną już w XIX w. pieczęć księżnej Kingi ${ }^{70}$. Na znanej skądinąd pieczęci tej władczyni widać pod gotyckim łukiem ukoronowaną, tronującą Marię z Dzieciątkiem, adorowaną przez kobiecą postać, ponad którą wznosi się anioł. Hipoteza wspiera się na przekonujących wynikach analizy ikonograficznej i epigraficznej. Na poparcie istnienia trzynastowiecznej pieczęci miejskiej Sandomierza przytacza się natomiast grafitowy odrys (tzw. wcierka) w materiałach Mariana Gumowskiego ${ }^{71}$. Autor tej koncepcji, H. Seroka, nie podał niestety sygnatury omawianego przez siebie obiektu. Reprodukowana przez niego podobizna trzynastowiecznej pieczęci znajduje się jednak na tablicy z wizerunkami pieczęci miejskich Sandomierza w materiałach M. Gumowskiego, a jej autopsja pozwala na stwierdzenie, że mamy do czynienia nie tyle ze wcierką, ile jedynie z rysunkiem ${ }^{72}$. Odwzorowana tam pieczęć różni się wprawdzie szczegółami ikonograficznymi i epigraficznymi od rysunku w pracy Balińskiego i Lipińskiego, ale odnieść można wrażenie, że różnice te wynikają nie tyle ze znajomości oryginalnego odcisku, co z próby skorygowania pewnych niezrozumiałych elementów wcześniejszych przedstawień. Pominięto krągły element w prawym (heraldycznie) górnym rogu łuku gotyckiego, powstały zapewne w wyniku zredukowania postaci anioła z pieczęci Kingi. W podobny sposób „poprawiono” treść legendy, stawiając na jej początku krzyż i korygując znak abrewiacyjny po literze $S$ w słowie $S$ (igillum). W znanym opracowaniu o pieczęciach miast polskich, gdzie znajduje się również zdjęcie omówionego pokrótce odrysu, M. Gumowski podał wymiary zgodne z wymiarami rysunku pieczęci w pracy Balińskiego i Lipińskiego, a następnie stwierdził, że „pieczęć taką znamy z rysunku w Starożytnej Polsce Balińskiego, gdzie podano, że to odwrocie (contrasigillum) na pieczęci dużej Leszka Czarnego z 1286 r., a ponieważ pieczęcie w tym wydawnictwie przerysowane są dosyć wiernie, więc i tu nie możemy mieć większych zastrzeżeń". W świetle zgromadzonych przesłanek wydaje się wątpliwe, aby M. Gumowski rzeczywiście odrysował oryginalny trzynastowieczny odcisk. Hipotezę taką można byłoby uargumentować jedynie za pomocą zachowanej wcierki. Na obecnym etapie badań przesłanki przemawiające za istnieniem trzynastowiecznej pieczęci sandomierskiej nie wytrzymują konfrontacji

${ }^{68}$ M. B a 1 i ń s k i, T. L i p i ń s k i, Starożytna Polska pod względem historycznym, jeograficznym i statystycznym opisana, t. II, Warszawa 1844, s. 268.

${ }^{69}$ Kraków, Muzeum Narodowe, VIII-rkps 563/133.

${ }^{70}$ M. S t a r z y ń s k i, Uwagi w sprawie genezy najstarszej pieczęci Krakowa z XIII wieku (na marginesie ostatnich badań), Studia Źródłoznawcze 50, 2012, s. 32-34.

${ }^{71}$ H. S e r o k a, Herby miasta królewskiego Sandomierza, s. 8-10.

72 Tamże, s. 9, ryc. 6-7. Kraków, Muzeum Narodowe, VIII-rkps 1469 t. 1. Tablicę publikuje D. O t w in o w s k a, Zbiory pieczęci w muzeum Narodowym w Krakowie i w Bibliotece XX Czartoryskich w Krakowie, w: Zbiory pieczęci w Polsce, Warszawa 2009, s. 161. 
z argumentami przeciwnymi - wskazać tu należy na nietypowy dla pieczęci miejskich kształt ostroowalny, przedstawienie dewocyjne oraz osobliwe posłużenie się tym tłokiem w roli contrasigillum dla pieczęci książęcej. Prawdopodobieństwo wzmocnienia pieczęci Leszka pieczęcią księżnej Kingi lub, co również możliwe, jego żony Gryfiny - wyglądu jej pieczęci jednak nie znamy - zdaje się natomiast wynikać z faktu dysponowania przez księżne krakowskie uposażeniem w Sandomierzu ${ }^{73}$.

Wójtowie i mieszczanie sandomierscy wzięli udział w burzliwych wypadkach towarzyszących powrotowi Władysława Łokietka do Małopolski w 1. 1305-1306, a potem w buncie miast małopolskich przeciwko jego panowaniu w 1. 1311-1312. Stłumienie buntu ugruntowało przewagę księcia nad miastami i jego sojusz polityczny z rycerstwem ${ }^{74}$. Władca zdołał podporządkować sobie także Sandomierz, osadzając na wójtostwie posłusznych sobie mieszczan krakowskich, Marka i Ruperta ${ }^{75}$. Nie wydaje się jednak, żeby współpraca z rodziną wójtów sandomierskich przerodziła się w konsekwentną politykę popierania rozwoju gminy miejskiej. Źródła informują przede wszystkim o fundacjach kościelnych pary książęcej. W 1315 r. księżna Jadwiga uprzywilejowała fundowany przez siebie beginaż sandomierski ${ }^{76}$. Beginki miały dysponować domem i placem położonym na północ od kolegiaty oraz ogrodem na przedmieściu, księżna zwolniła je jednak z opłat na rzecz miasta i ze stróży przy murach miejskich. W 1321 r. Władysław z Jadwigą ufundowali nową prebendę przy kolegiacie, którą uposażyli w przysługujące władcy 4 grzywny czynszu miejskiego z domów, winnic i ogrodów oraz w należące do księżnej 4 grzywny z cła sandomierskiego ${ }^{77}$. Uwagę władcy przyciągał na pewno gród sandomierski. W $1328 \mathrm{r}$. Mikołaj Ciołek, podkomorzy i dzierżawca dóbr sandomierskich z łaski Łokietka, zobowiązał się przeznaczyć cały płynący z nich czynsz pro muris et aliis edificiis et laboribus prefati castri Sandomiriensis ${ }^{78}$. Sytuacja miasta uległa znaczącej poprawie za panowania Kazimierza Wielkiego, który, w przeciwieństwie do swojego ojca, uprawiał bardziej świadomą politykę popierania rozwoju miast ${ }^{79}$. W 1337 r. potwierdził

73 J. P t a k, Związki Świętej Kingi z Sandomierzem, w: Pani Sądecka. Aktualność Świętej Kingi, Sandomierz 2000, s. 40-48; A. Te t e r y c z - P u z i o, Geneza, s. 164. Szerzej zob. t a ż, Kilka uwag o działalności politycznej księżnych krakowskich w okresie rozbicia dzielnicowego, Res Historica 26, 2008, s. 9-29.

${ }^{74}$ S. G a w l a s, O kształt, s. 93-95; J. K u r t y k a, Odrodzone Królestwo. Monarchia Władysława Łokietka i Kazimierza Wielkiego w świetle nowszych badań, Kraków 2001, s. 16-17, 176 n.; A. M a r z e c, Geneza stronnictwa „panów krakowskich” w późnośredniowiecznej Polsce, w: Kazimierz Wielki i jego państwo, Bydgoszcz 2011, s. 127-138.

75 J. P t a śn i k, Studia, cz. 1, s. 34.

${ }^{76}$ KDM II, nr 561; zob. D. L a p i s, Beginki w Polsce w XIII-XV wieku, Kwartalnik Historyczny 79, 1972, s. 526, 530.

77 KDM II, nr 581; LB I, s. 371; zob. L. P o n i e w o zi k, Prałaci, s. 36-37.

${ }^{78}$ Dokumenty kujawskie i mazowieckie przeważnie z XIII wieku, wyd. B. Ulanowski, Kraków 1888 (Archiwum Komisji Historycznej AU, t. IV), nr 165; A. M ił o b ę d z k i, Zamek sandomierski, w: Studia sandomierskie (jak w przyp. 4), s. 247; M. F1 o r e k, Zabudowa Wzgórza Zamkowego w Sandomierzu w średniowieczu, w: Późnośredniowieczne zamki na terenie dawnego województwa sandomierskiego, Kielce 2005, s. 100; t e n że, Sandomierski ośrodek, s. 46.

79 S. G a w l a s, Uwagi o polityce miejskiej Kazimierza Wielkiego, w: Aetas media, aetas moderna. Studia ofiarowane profesorowi Henrykowi Samsonowiczowi w siedemdziesiątą 
wójtom sandomierskim prawa do wsi Radoszki, nadanej im wraz z Ocinem jeszcze przez Łokietka w 1307 r., zaznaczył jednak, że powinna ona stanowić wspólną własność wójtów i mieszczan ${ }^{80}$. W 1349 r. król zezwolił mieszczanom sandomierskim na budowę łaźni ${ }^{81}$, a z dokumentu z 1399 r. wynika, że w nieokreślonym czasie sprzedał im też 6 jatek rzeźniczych za 120 grzywien $^{82}$. Zgodnie z informacjami zawartymi w czternastowiecznej Kronice katedralnej krakowskiej i powtórzonymi potem przez Jana Długosza, Kazimierzowi przypisuje się jednak całościową przebudowę miasta ${ }^{83}$. Miała ona polegać na wzniesieniu gotyckiego zamku, do czego przystąpiono być może w $1349 \mathrm{r}^{84}$, i otoczeniu miasta fortyfikacjami (może około 1362 r.), które ostatecznie połączono z zamkiem ${ }^{85}$. Doszło również do prawie dwukrotnego powiększenia miejskiego terytorium. Do najważniejszych nabytków miasta na północy należały rejon kościoła i szpitala Świętego Ducha, a na południu i południowym wschodzie Wzgórze Katedralne z podgrodziem i kolegiatą oraz Wzgórze Gostomianum z kościołem parafialnym św. Piotra ${ }^{86}$. Zarówno kolegiata, jak i kościół św. Piotra zostały prawdopodobnie przebudowane ze środków króla ${ }^{87}$. Zapewne przy

rocznicę urodzin, Warszawa 2000, s. 25-41. Por. A. P a w ł o w s k a - O b a r a, Polityka gospodarcza Władysława Łokietka, Lublin 2014.

${ }^{80}$ CDP I, nr 109. Dokument Łokietka: KDM I, nr 137. Późniejsze losy tych wsi omawia J. Mus z yń s k a, Spory miasta Sandomierza z chłopami ze wsi miejskich w XVII i XVIII wieku, w: Księga jubileuszowa Profesora Feliksa Kiryka, Kraków 2004 (Annales Academiae Paedagogicae Cracoviensis 21, Seria Historica 3), s. 355-360.

81 KDM I, nr 228.

82 KDM IV, nr 1050. Zob. także KDM III, nr 808.

${ }^{83}$ Kronika katedralna krakowska, fragment wydany jako Kronika Jana z Czarnkowa, Monumenta Poloniae historica, t. II, s. 625; Annales, lib. IX, s. 349. Zob. T. P o k le w s k i, Przydatność tekstu Quomodo regebat regnum et populum do badań wielkości inwestycji obronnych Kazimierza Wielkiego, Kwartalnik Architektury i Urbanistyki 40, 1995, z. 1, s. 63-67.

${ }^{84}$ A. M ił o bę d z k i, Zamek sandomierski, s. 251-254; J. Wi d a w s k i, Miejskie mury obronne w państwie polskim do początku XV wieku, Warszawa 1973, s. 400-417; M. F 1 o r e k, Zabudowa Wzgórza Zamkowego, s. 46. Przyjmowana data opiera się na informacji podanej przez Długosza (Annales, lib. IX, s. 256), według którego w tym roku król miał pociągać bezprawnie do danin i robocizny ludność biskupiego klucza złockiego pod Sandomierzem. W literaturze wzmiankuje się też stanowisko M. B u 1 iń s k i e g o, Monografia, s. 54, który na ten właśnie rok datował najazd Litwinów i pożar miasta. Historyczność tego wydarzenia podaje się jednak aktualnie w wątpliwość, o czym niżej. Pierwsza wzmianka o murze zamkowym pochodzi z 1394 r. (Rachunki dworu króla Władysława Jagiełły i królowej Jadwigi z lat 1388 do 1420, wyd. F. Piekosiński, Kraków 1896, s. 183: Item Wylhelmo procuratori Sandomiriensi super labore ibidem muri in castro, ad mandatum dni Regis vocale XX marc.).

${ }_{85}$ Rozpoczęcie budowy fortyfikacji na $1362 \mathrm{r}$. kładzie, bez powołania się na żadne źródło, M. B u 1 i ń s k i, Monografia, s. 53, a za nim późniejsza literatura (np. J. W i d a w s k i, Miejskie mury obronne, s. 405). Nie można wykluczyć, że Buliński znał jakiś niezachowany obecnie dokument, w którym wzmiankowano mur miejski. Zob. M. Fl o r e k, Zabudowa, s. 101.

${ }^{86}$ B. K r a s n ow o $1 \mathrm{~s} \mathrm{ki}$, Poszerzenie układu urbanistycznego centrum po 1349 roku analiza modularna, w: Atlas historyczny miast polskich, t. V, z. 2, Sandomierz-Kraków 2014, s. 9-10; M. F 1 o r e k, Sandomierski ośrodek, s. 47.

87 Źródła informują o przebudowie kolegiaty: Kronika katedralna krakowska, Monumenta Poloniae historica, t. II, s. 624; Annales, lib. IX, s. 265, 349. O udziale króla w przebudowie kościoła św. Piotra ok. 1353 r. informuje M. B u l iń s k i, Monografia, s. 371, który dysponował niezachowanym spisem przywilejów tej świątyni, zob. M. K u n k e 1, P. M ro z o w s ki, 
tej okazji zlikwidowano pozostałości dawnych obwarowań podgrodzia, zasypując głęboki parów oddzielający wzgórza Katedralne i Miejskie ${ }^{88}$.

Regulacje urbanistyczne na nowych terenach miejskich miały jednak bardzo ograniczony zasięg. Ominęły one w większości rejon kościoła św. Piotra, gdzie uniemożliwiał je ostry spad skarpy, a zapewne też obecność własności kościelnej. $\mathrm{Z}$ powodu koncentracji tej ostatniej niemożliwe było tym bardziej przeprowadzenie regulacji na terenie podgrodzia - w późniejszym czasie oprócz cmentarza w okolicy kolegiaty znajdowały się domy 12 prałatów i kanoników, dom wikariuszy, dom świątników, szkoła, domek jej rektora i beginaż ${ }^{89}$. Włączenie podgrodzia w obręb lokacyjnego Sandomierza nie odbyło się bez sporów z Kościołem. Ich sens może uzmysławiać m.in. zrealizowana przez Kazimierza inicjatywa połączenia miasta lokacyjnego w Płocku z biskupim podgrodziem, wpisująca się w działania zapoczątkowane jeszcze przez księcia Konrada mazowieckiego ${ }^{90}$. Pośrednim świadectwem konfliktów własnościowych na terenie Sandomierza wydaje się zwłaszcza wzmianka w dokumencie sądu ławniczego z 1399 r., informująca o sprzedaniu mieszczanom przez króla w nieznanym czasie sześciu jatek rzeźniczych. Miało to wywołać niezadowolenie u prepozyta kolegiaty, który starał się następnie uzurpować sobie te dochody, w ostateczności jednak jatki zostały przywrócone mieszczanom przez władcę ${ }^{91}$. Możliwe, że w ramach rekompensaty król zezwolił w 1356 r. kustoszowi kolegiaty na budowę karczmy w Piekarach i włączenie jej do prebendy kustodii ${ }^{92}$. Przypomnijmy, że dobra w Piekarach włączył do kustodii jeszcze Łokietek, traktując to nadanie jako zadośćuczynienie strat materialnych poniesionych przez kolegiatę z powodu lokacji. Zmiany własnościowe w Sandomierzu uderzały również w interesy klasztoru cysterskiego w Koprzywnicy. W 1371 r. cystersi odkupili od pewnego mieszczanina dwie jatki rzeźnicze odebrane im przez króla Kazimierza non ex demerito culpe monasterii, a także dwie kolejne, należące do mieszczan również $\mathrm{z}$ nadania tego władcy ${ }^{93}$. Rozbudowa miasta i zamku przebiegała też równolegle

Kościół św. Piotra w Sandomierzu. Analiza historyczno-architektoniczna, w: Sandomierz: badania (jak w przyp. 3), t. II, s. 145-147.

${ }^{88}$ E. G ą s s o w s k a, Badania wykopaliskowe w Sandomierzu w latach 1958-1968, Sprawozdania Archeologiczne 22, 1970, s. 220-222; A. B u k o, Wzgórze Katedralne, w: Sandomierz: badania (jak w przyp. 3), t. I, s. 199-304; t e n ż e, Początki Sandomierza, s. 100; M. F l o r e k, Sandomierski ośrodek, s. 27, 34.

${ }^{89}$ T. L a l i k, Domy kanoników kapituły sandomierskiej w średniowieczu, w: Sandomierz: badania (jak w przyp. 3), t. I, s. 73-79.

${ }^{90}$ S. M. S z a c h e r s k a, Płock - civitas vetus czy civitas cathedralis?, w: Społeczeństwo Polski średniowiecznej, t. V, Warszawa 1992, s. 186-187; S. G a w l a s, Uwagi, s. 32-33.

91 KDM IV, nr 1050: serenissimum principem dominum ac dominum pie memorie Kazimirum regem Polonie quondam quibusdam civibus dicte Sandomirensis civitatis sex macella carnium pro centum et viginti marcis Polonicalibus vendidisse, de quibus Bozanta Sandomiriensis protunc prepositus contra iusticiam ipso rege ignorante, seductus per se sine velle civium fructus usurpavit, demum quod rex percipiens motus zelo iusticie ipsis civibus omnes proventus dictorum macellorum mandans restitui ordinavit.

${ }^{92}$ KDM I, nr 248. W 1366 r. Kazimierz zezwolił też dziekanowi Michałowi, swemu kapelanowi, przenieść na prawo średzkie cztery wsie należące do dziekanii (KDM I, nr 282).

${ }_{93} \mathrm{KDM}$ III, nr 841: que macella non ex demerito culpe monasterii potencia regali sive regis olim Kazimiri beate memorie sunt ablate seu recepte. Por. LB III, s. 378. Nie była 
z zatargiem władcy z biskupem. Długosz wzmiankuje, że w 1349 r. Bodzęta miał sprzeciwiać się bezprawnemu pociąganiu ludności biskupiego klucza złockiego koło Sandomierza do danin i robocizn na rzecz władcy ${ }^{94}$. Informację tę wiąże się zazwyczaj z datowanymi właśnie na ten czas pierwszymi robotami budowlanymi przy zamku5.

W całej dotychczasowej literaturze, poczynając od wypowiedzi M. Bulińskiego z 1879 r., panuje przekonanie, że reformy osadnicze Kazimierza Wielkiego na terenie Sandomierza miały na celu podniesienie miasta ze zniszczeń spowodowanych przez najazd litewski z 1349 r. ${ }^{96}$ Przypomnijmy, że rzeczywiście z tego właśnie roku pochodzi przywilej królewski w sprawie budowy łaźni w mieście. Data wskazana przez Bulińskiego została następnie skorygowana na rok 1350, ale historyczność samego najazdu jest ostatnio w przekonujący sposób podważana ${ }^{97}$. Nie wnikając w szczegóły tej dyskusji, należy raczej podkreślić, że postępowanie króla wpisywało się w ogólniejszą, świadomie wdrażaną wizję reformy stosunków miejskich. Dokonujący się za jego panowania rozwój Sandomierza koresponduje zwłaszcza z równoczesnym ożywieniem ruchu handlowego na szlakach łączących Węgry i Ruś ze Śląskiem i wybrzeżem Morza Bałtyckiego. Wzrost koniunktury miał niewątpliwy związek ze staraniami władcy na rzecz reorganizacji wymiany handlowej na szlakach łączących Prusy i ziemie polskie z Rusią. W dalszej perspektywie reformy królewskie miały prowadzić do przejęcia zysków z ruchu tranzytowego przez odsunięcie go od granic Mazowsza i popieranie wymiany handlowej na trakcie do Lwowa kosztem popularnej drogi do Włodzimierza, na której rozwinęła się m.in. Warszawa $^{98}$. Do najważniejszych świadectw źródłowych działań reformatorskich Kazimierza w dziedzinie polityki handlowej zalicza się niedatowany spis komór celnych

to jedyna konfiskata, która spadła na wspomniane opactwo. W 1338 król zwrócił cystersom bezprawnie zajętą łąkę w Krzcinie, a w 1368 r. wymógł na nich oddanie dochodowego Jasła i wsi Pukarzew w zamian za dwie inne wsie (Z. K o złow s k a - B udk ow a, S. S z c z u r, Dzieje opactwa cystersów w Koprzywnicy do końca XIV wieku, Nasza Przeszłość 60, 1983, s. 55-57; J. W y r o z u m s k i, Początki miast w regionie jasielskim, w: Studia z dziejów Jasła i powiatu jasielskiego, Kraków 1964, s. 74-75).

${ }^{94}$ Annales, lib. IX, s. 256: villas Zlotensis tenute episcopales, que prope Sandomiriam consistunt, per Otthonem de Pilcza pallatinum et capitaneum Sandomiriensem, de domo Bipennium, tributis et laboribus servire cogebat. Zob. M. N i w i ń s k i, Biskup krakowski Bodzanta i Kazimierz Wielki, Collectanea Theologica 17, 1936, z. 1-2, s. 237-238; B. W y r o z u m s k a, Otto z Pilicy, w: Polski słownik biograficzny, t. XXIV (1979), s. 634; S. I n g l o t, Stan i rozmieszczenie uposażenia biskupstwa krakowskiego w połowie XV wieku. Próba odtworzenia zaginionej części Liber beneficiorum Długosza, Lwów 1925, s. 38-39.

${ }_{95}$ A. Miło bę d z k i, Zamek sandomierski, s. 250-251. Zob. też wyżej, przyp. 84-85.

${ }_{96}$ M. B ulińs ki, Monografia, s. 54; W. Kalin ow ski, T. Lalik, T. Przypk ow ski, H. Rutk ow ski, S. Tr a w k ow ski, Sandomierz, s. 24; M. F lor e k, Sandomierski ośrodek, s. 46.

97 S. S z c z u r, W sprawie sukcesji andegaweńskiej w Polsce, Roczniki Historyczne 75, 2009, s. 91-95. O zdobyciu Sandomierza przez pogan wspomina się jedynie w suplice królewskiej do papieża z 1360 r., nie wiadomo jednak, do jakiego wydarzenia odnosi się ta wzmianka (t e n ż e, Supliki Kazimierza Wielkiego, Roczniki Historyczne 59, 1993, s. 74-76).

${ }^{98} \mathrm{H}$. S a m s o n o w i c z, Przemiany osi drożnych w Polsce późnego średniowiecza, Przegląd Historyczny 64, 1973, s. 697-716; A. O rł o w s k a, W sprawie polityki handlowej Kazimierza Wielkiego, w: Z dziejów średniowiecznej Europy Środkowo-Wschodniej. Zbiór studiów, cz. 2, Warszawa 2007 (Fasciculi Historici Novi, 6), s. 153-165; S. G a w l a s, Uwagi, s. 39. 
i mytniczych, opisujący również dwie drogi łączące Toruń ze Lwowem, z których drugą określono jako „nową"99. Wiodła ona przez Brześć, Przedecz, Łęczycę, Inowłódz, Opoczno, Radom, Opatów, Sandomierz, Jarosław i Przemyśl. Intensyfikacja ruchu na opisanym szlaku na pewno stwarzała podstawy do rozwoju położonych na nim miast, partycypujących $\mathrm{w}$ zyskach $\mathrm{z}$ tranzytu ${ }^{100}$. Zwracano już uwagę, że ośrodki miejskie wymienione w opisie nowej drogi z Torunia do Lwowa cieszyły się na ogół wyraźną opieką monarchy ${ }^{101}$. Problem ten wymaga $\mathrm{z}$ pewnością dalszych badań. Nie mnożąc możliwych analogii, poprzestańmy na stwierdzeniu, że zależność taką widać zwłaszcza na słabiej zurbanizowanym, środkowym odcinku szlaku. Uwagę zwracają dokonane tu około połowy XIV w. lokacje trzech, mniej do tej pory znaczących ośrodków miejskich, Inowłodza, Opoczna i Radomia. Każda z tych operacji uwzględniała zaprowadzenie prawa miejskiego w wersji magdeburskiej (w Opocznie i Radomiu zastąpiło ono wcześniejsze prawo średzkie) oraz translokację osadnictwa miejskiego, wytyczenie regularnego szachownicowo-blokowego układu zabudowy z rynkiem, otoczenie miasta murem i budowę zamku sprzężonego z miejskim systemem obronnym ${ }^{102}$. Przekształcenia miast na szlakach wymiany dalekiej nie ominęły z pewnością Sandomierza ${ }^{103}$. Ambicje mieszczan, uczestniczących także w ruchu handlowym na szlaku prowadzącym na Węgry, wywołały opór ze strony kupców krakowskich. Już w 1332 r. sprzeciwiali się oni, początkowo bezskutecznie, nadaniu sandomierzanom wolnego przejazdu przez Żmigród, godzącego w przysługujący im przymus drożny. Mimo początkowej kontynuacji polityki ojca, w $1356 \mathrm{r}$. Kazimierz potwierdził krakowski przymus drożny ${ }^{104}$. Kupcy sandomierscy zrekompensowali sobie tę stratę prawem składu na sól i śledzie, przejętym od Opatowa w 1366 r. Egzekwowanie go stało się powodem wieloletnich sporów z innymi miastami Małopolski ${ }^{105}$.

Można domniemywać, że rozbudowie przestrzennych i materialnych podstaw sandomierskiego miasta lokacyjnego towarzyszyły przekształcenia prawnoustrojowe. Korelację taką widać bardzo wyraźnie np. w Kaliszu. Tamtejsze trzynastowieczne miasto lokacyjne zostało przeniesione przez króla Kazimierza w nowe miejsce,

${ }^{99}$ Hansisches Urkundenbuch, t. III, wyd. K. Höhlbaum, Halle 1882-1886, nr 559. Zob. S. W e y m a n n, Cła i drogi handlowe w Polsce piastowskiej, Poznań 1938, s. 51-52, 101-102; A. Orłow sk a, W sprawie polityki, s. 153-165.

100 A. B e r d e c k a, Lokacje, s. 40.

101 J. A u g u s t y n i a k, Zamek w Inowłodzu, Łódź 1992, s. 102-103.

102 J. W i d a w s k i, Miejskie mury obronne, s. 139-142, 328-332, 383-394; t e n ż e, Zamek i mury miejskie Inowłodza na tle podobnych obiektów w Polsce, w: Problemy badawcze średniowiecznego Inowłodza, Łódź 1980, s. 56-63; T. Z a r ę b s k a, Z zagadnień urbanistycznych Inowłodza, tamże, s. 70-71; J. A u g u s ty n i a k, Zamek w Inowłodzu; R. S z c z y g i e 1, Powstanie nowego Nowego Miasta w Radomiu, w: Radom. Lokacja miasta, odkrywanie zamku, Radom 2001, s. 23-24; Z. Gu 1 d o n, J. Mu s z y ń s k a, Powstanie i dzieje miasta w okresie przedrozbiorowym (do 1795 r.), w: Opoczno. Studia i szkice z dziejów miasta, Kielce 2003, s. 34-37; Z. L e c h ow i c z, Zamek w Radomiu. Archeologia i architektura, badania i interpretacje, Radom 2012.

103 Z. M or a w s k i, Sandomierz, s. 125-127.

104 Kodeks dyplomatyczny miasta Krakowa, t. I, wyd. F. Piekosiński, Kraków 1874, nr 32.

105 CDP III, nr 142. Zob. Z. M or a w s k i, Sandomierz, s. 127; F. K i r y k, Urbanizacja Małopolski, s. 89, 123. 
gdzie następnie wytyczono regularny układ zabudowy, wzniesiono mury miejskie i sprzężony $\mathrm{z}$ nimi zamek ${ }^{106}$. Również $\mathrm{w}$ tym przypadku widoczny jest ewidentny związek między rozbudową miasta a wzrostem gospodarczego znaczenia w systemie reorganizowanej sieci szlaków handlowych. We wspomnianym spisie komór wymieniono dwie drogi (starszą i młodszą) łączące Toruń z Wrocławiem, przy czym komora w Kaliszu figuruje w opisie drogi nowej ${ }^{107}$. Zapewne w związku z awansem znaczenia tego połączenia w 1349 r. monarcha poparł inicjatywę zawarcia przez Wrocław i Kalisz konfederacji w celu wspólnego ścigania przestępców ${ }^{108}$. Rozbudowa miasta wiązała się również z bardziej zasadniczymi przeobrażeniami ustroju miejskiego. W 1360 król zatwierdził wykupienie przez rajców wójtostwa dziedzicznego i odnowił prawa miejskie Kalisza, natomiast w 1365 r. podtrzymał istnienie kaliskiego sądu wyższego prawa średzkiego - wbrew tendencji do zastępowania go prawem magdeburskim - i zastrzegł, że funkcję ławników powinni pełnić w nim mieszczanie, rozciągnął także wyroki proskrypcji wydawane przez sąd miejski na wszystkie inne miasta rządzące się prawem kaliskim ${ }^{109}$. W Sandomierzu, jak wspominałem, proces formowania ustroju samorządowego opartego na wzorcu magdeburskim zapoczątkowała już lokacja z 1286 r., a wyrazem rosnącej samodzielności mieszczan był ich udział w buncie przeciwko księciu w 1. 1311-1312. Nie dysponujemy przekazami informującymi o regułach funkcjonowania w Sandomierzu ustroju samorządowego w omawianym okresie. Dostępne źródła dokumentują natomiast proces formowania kancelarii miejskiej, której rozbudowa odpowiadała zapewne rosnącym potrzebom administracyjnym. Nie można wykluczyć, że jeszcze przed wspomnianym buntem miasto dysponowało własną pieczęcią, choć nie ma na to żadnych dowodów. Przesłanki ikonograficzne pozwalają hipotetycznie datować najstarszą znaną sandomierską pieczęć miejską dopiero na lata panowania Władysława Łokietka, zapewne po jego koronacji królewskiej w 1320 r. ${ }^{110}$ Pieczęć ta została przywieszona po raz pierwszy do dokumentu z 1343 r., mocą którego władze Krakowa, Sandomierza i Nowego Sącza zobowiązywały się do przestrzegania pokoju polsko-krzyżackiego ${ }^{111}$. W polu pieczęci przedstawiono mur miejski z bramą i dwiema basztami. Nad bramą znajduje się zwrócona w kurtuazyjnym skłonie trójkątna tarcza z koronowanym orłem, zwieńczona hełmem z labrami i pióropuszem. Legenda w jej otoku brzmi: + S(igillum) REGIS : POLONIE - ET · CIVITATIS · SANDOMIRIE. Hełm z pióropuszem został

106 J. W i d a w s k i, Miejskie mury obronne, s. 158-159; T. P o k l e w s k i, Miejsce zamku w systemie obronnym miasta $\mathrm{w}$ wiekach XIV i XV w Polsce, w: Czas, przestrzeń, praca w dawnych miastach. Studia ofiarowane Henrykowi Samsonowiczowi w sześćdziesiątą rocznicę urodzin, Warszawa 1991, s. 61-72; M. Ż e mig ała, Datowanie planu miasta Kalisza w świetle najnowszych badań archeologicznych, Kwartalnik Architektury i Urbanistyki 38, 1993, z. 2, s. 119-124.

${ }^{107}$ S. We y m a n n, Cła, s. 50-51, 101.

108 Kodeks dyplomatyczny Wielkopolski, t. II, [wyd. I. Zakrzewski], Poznań 1877, nr 1287.

109 Tamże, t. III (1878), nr 1414, 1549. Zob. A. W ę d z k i, Ustrój miasta w okresie późnego średniowiecza, w: Dzieje Kalisza, Poznań 1977, s. 80-81.

${ }^{110}$ M. R o k o s z, ,Sigillum regis... et civitatis”. O pieczęci wielkiej Sandomierza, w: Heraldyka i okolice, Warszawa 2002, s. 311-321.

${ }_{111}$ CDP I, nr 111. Zob. M. S t a r z y ń s ki, Krakowska rada miejska w średniowieczu, Kraków 2010, s. 201-202. 
zapewne przejęty z repertuaru znaków władzy Władysława Łokietka ${ }^{112}$, był mianowicie eksponowany na jego pieczęci pieszej z około 1313 r. i na denarach krakowskich, emitowanych po 1320 r. ${ }^{113}$ Napis w otoku określa władcę jako współdysponenta pieczęci, manifestując królewską zwierzchność nad Sandomierzem i podkreślając polityczną rangę miasta. Awansowi politycznemu Sandomierza sprzyjało z pewnością podniesienie miasta w 1336 r. przez Kazimierza Wielkiego do rangi siedziby zamkowego sądu wyższego prawa niemieckiego ${ }^{114}$. Działania władcy wpisywały się w przypadający na okres jego panowania proces umacniania autorytetu przepisów prawa niemieckiego w Królestwie ${ }^{115}$. Raczej nieprzypadkowo właśnie w 1359 r. sandomierski pisarz miejski Konrad sporządził łacińskie tłumaczenie Zwierciadła saskiego. Warto podkreślić, że zostało ono wykonane na polecenie tutejszego mieszczanina, Mikołaja z Pacanowa ${ }^{116}$. Nieprzypadkowo też w połowie XIV w. źródła zaczynają przynosić bogatsze informacje o kancelarii miejskiej. Dokument z 1356 r., regulujący kwestie podziału majątkowego między potomstwem wójtów sandomierskich, wzmiankuje ,pieczęcie wójta, miasta i ławników”"117. Własną pieczęcią, przedstawiającą ukoronowanego połuorła, posługiwało się w tym czasie na pewno kolegium ławników, którzy w 1367 r. wystawili pierwszy znany nam dokument w sprawie podziału majątkowego ${ }^{118}$. Ikonografia znanej z późniejszego odcisku pieczęci mniejszej z wyobrażeniem króla w majestacie pozwala domniemywać, że również ona powstała za życia Kazimierza Wielkiego ${ }^{119}$. W 1367 r. wzmiankowany jest już kolejny pisarz miejski ${ }^{120}$. Brak ksiąg wpisów, zachowanych dopiero od XVI w., a także niewielka liczba zachowanych dokumentów z tego czasu uniemożliwia bliższą obserwację sandomierskiej kancelarii miejskiej w XIV w. Można jedynie zwrócić uwagę, że odbiorcą wszystkich trzech najstarszych dokumentów wystawionych w imieniu władz miejskich, pochodzących z lat 1367, 1368 i 1371, był klasztor cysterski

112 M. Gu mo w s k i, Najstarsze pieczęcie, s. 192-193.

113 B. P a s z k i e w i c z, Mennictwo Władysława Łokietka, Wiadomości Numizmatyczne 30, 1986, z. 1-2, s. 32-35, 53-57; Z. P i e c h, Ikonografia pieczęci Piastów, Kraków 2003, s. $217-218$.

114 KDM I, nr 204. Zob. S. E hrenkre utz, Sąd wyższy prawa niemieckiego grodu sandomierskiego, w: Pamiętnik trzydziestolecia pracy naukowej profesora Przemysława Dąbkowskiego, Lwów 1927, s. 281-294; L. Ł y s i a k, Sąd wyższy prawa niemieckiego na zamku krakowskim a inne sądy wyższe z terenu Małopolski, Śląski Kwartalnik Historyczny Sobótka 48, 1993, z. 2-3, s. 113-122.

115 S. G a w 1 a s, Uwagi, s. 34-35.

116 Z. Ry mas z e w s k i, Łacińskie teksty Landrechtu Zwierciadła Saskiego w Polsce. Versio Vratislaviensis, versio Sandomiriensis, Łaski, Wrocław 1975, s. 69, 77; K. K a m i ń s k a, Lokacje, s. $58 \mathrm{n}$.

117 KDM I, nr 247.

118 KDM III, nr 804; F. P i e k o s i ń s k i, Pieczęcie polskie wieków średnich, cz. 1, Kraków 1899, s. 212; M. Gu m o w s k i, Najstarsze pieczęcie, s. 194; H. S e r o k a, Herby miast małopolskich, s. 103-104. Najstarsza znana wzmianka o alienacji gruntu wobec wójta i ławników odnosi się natomiast już do 1331 r. (LB III, s. 53).

119 M. H a is i g, Nieznana pieczęć miasta Sandomierza, Miesięcznik Heraldyczny 17 , 1938, z. 9, s. 134-135; M. G u m o w s k i, Najstarsze pieczęcie, s. 193-194; H. S e r o k a, Herby miast małopolskich, s. 103-104.

120 KDM III, nr 804. 
w Koprzywnicy ${ }^{121}$. Dyplomy te mogą oczywiście stanowić niewielką część wytworów kancelarii miasta, uwypuklają jednak podkreślany w polskiej literaturze związek między rozwojem dokumentu miejskiego a interesami i potrzebami klasztorów ${ }^{122}$.

W świetle powyższych rozważań Sandomierz około połowy XIV w. prezentuje się jako ukształtowane miasto, o stabilnej sytuacji własnościowej, przestrzennej i prawnoustrojowej, opierające swoje gospodarcze znaczenie na zyskach z handlu dalekosiężnego. Formowanie ośrodka miejskiego nie sprowadzało się jednak bynajmniej do jednorazowej operacji osadniczej. Pomimo trudności wynikających ze skomplikowanych warunków topograficznych, wyniszczających skutków napadu tatarskiego oraz ciągłego ryzyka kolejnych najazdów, proces kształtowania Sandomierza przebiegał według czytelnego wzorca. Składał się on z kilku nierównomiernie udokumentowanych faz. Pierwszą z nich było utworzenie autonomicznej gminy kupieckiej w sąsiedztwie kościoła św. Pawła na Wzgórzach Staromiejskich w pierwszej ćwierci XIII w., prawdopodobnie za rządów Leszka Białego. Jej rozwój został wstrzymany lub spowolniony w wyniku najazdu tatarskiego z 1. 1259-1260. Drugi etap przekształceń lokacyjnych polegał na przenosinach zwartego osadnictwa na Wzgórze Miejskie oraz zaszczepieniu tam prawa magdeburskiego z zalążkami samorządu komunalnego i wytyczeniu szachownicowo-blokowego układu zabudowy. Trzecia, zdecydowanie najsłabiej zbadana faza kształtowania sandomierskiego ośrodka miejskiego, przypadła już na okres panowania Kazimierza Wielkiego. Polegała na rozbudowie przestrzennej miasta i umocnieniu jego pozycji na szlakach dalekosiężnej wymiany handlowej. Reformy Kazimierza odcisnęły też zapewne piętno na organizacji miejskiego sądownictwa oraz aktywności samorządu i działającej u jego boku kancelarii. Wbrew poglądowi wyrażanemu w całej dotychczasowej literaturze, nie ma powodu, by sądzić, że działania króla były jedynie próbą podźwignięcia miasta z upadku po rzekomym najeździe litewskim z 1350 r. Przeobrażenia miasta z czasów Kazimierza, tak jak pozostałe wskazane etapy procesu miastotwórczego, znajdują wiele interesujących analogii $\mathrm{w}$ dziejach innych polskich miast tego czasu i odbijają szersze procesy oraz standardy polityki miejskiej. Ich wdrażanie, podobnie jak w innych liczących się ośrodkach, napotykało zrozumiały opór ze strony instytucji kościelnych, które eliminowano z udziału w zyskach z rozwijającego się miasta.

\section{BIBLIOGRAFIA}

Antosiewicz K., Szpital i kościół św. Ducha w Sandomierzu, Studia Sandomierskie 2, 1981. Augustyniak J., Zamek w Inowłodzu, Łódź 1992.

Baliński M., Lipiński T., Starożytna Polska pod względem historycznym, jeograficznym i statystycznym opisana, t. II, Warszawa 1844.

Berdecka A., Lokacje i zagospodarowanie miast królewskich w Małopolsce za Kazimierza Wielkiego (1333-1370), Wrocław 1982.

Buko A., Najstarsze kościoły dominikańskie w przestrzeni ośrodków wczesnomiejskich na ziemiach polskich, w: Dominikanie. Gdańsk - Polska - Europa, Gdańsk-Pelplin 2003.

Buko A., Początki Sandomierza, Warszawa 1998.

121 Tamże, nr 804, 808, 841.

${ }^{122}$ K. S k u p i eń s k i, Klasztory a początki dokumentu miejskiego w Polsce, w: Klasztor W mieście średniowiecznym (jak w przyp. 56), s. 93-102. 
Buko A., Sandomierz wczesnopiastowski, w: Dzieje Sandomierza, t. I, Warszawa 1993.

Buko A., Warunki naturalne Sandomierza i elementy pierwotnej rzeźby terenu, w: Sandomierz: badania 1969-1973, t. I, Warszawa 1992.

Buko A., Wzgórza Staromiejskie, w: Sandomierz: badania 1969-1973, t. I, Warszawa 1992.

Buko A., Wzgórze Katedralne, w: Sandomierz: badania 1969-1973, t. I, Warszawa 1992.

Buliński M., Monografia miasta Sandomierza, Warszawa 1879.

Burdzy D., Sandomierski klasztor św. Marii Magdaleny w średniowieczu, Nasza Przeszłość 108, 2007.

Derwich M., Benedyktyński klasztor św. Krzyża na Łysej Górze w średniowieczu, Warszawa-Wrocław 1992.

Dzieje Sandomierza, red. H. Samsonowicz, t. I: Średniowiecze, red. S. Trawkowski, Warszawa 1993.

Ehrenkreutz S., Sąd wyższy prawa niemieckiego grodu sandomierskiego, w: Pamiętnik trzydziestolecia pracy naukowej profesora Przemysława Dąbkowskiego, Lwów 1927.

Estreicher S., Kraków i Magdeburg w przywileju fundacyjnym krakowskim, w: Ku uczczeniu Bolesława Ulanowskiego, Kraków 1911.

Europejskie miasta prawa magdeburskiego. Tradycja, dziedzictwo, identyfikacja, Kraków 2007.

Florek M., Kościół św. Jakuba i dawny klasztor dominikanów w Sandomierzu. Wyniki badań archeologiczno-architektonicznych, Kwartalnik Historii Kultury Materialnej 42, 1994, z. 1.

Florek M., Najstarsze fortyfikacje miejskie Sandomierza w świetle ostatnich odkryć archeologicznych, Sprawozdania Archeologiczne 55, 2003.

Florek M., Sandomierski ośrodek grodowo-miejski w średniowieczu. Przemiany przestrzenne i funkcjonalne, Warszawa 2005.

Florek M., Zabudowa Wzgórza Zamkowego w Sandomierzu w średniowieczu, w: Późnośredniowieczne zamki na terenie dawnego województwa sandomierskiego, Kielce 2005.

Gawlas S., O kształt zjednoczonego Królestwa. Niemieckie władztwo terytorialne a geneza społeczno-ustrojowej odrębności Polski, wyd. 2, Warszawa 2000.

Gawlas S., Przełom lokacyjny w dziejach miast środkowoeuropejskich, w: Civitas Posnaniensis. Studia z dziejów średniowiecznego Poznania, Poznań 2005.

Gawlas S., Ulica a zmiany krajobrazu miejskiego w okresie lokacji, Kwartalnik Historii Kultury Materialnej 47, 1999, z. 1-2.

Gawlas, S., Ustrojowe i społeczne uwarunkowania lokacji miejskich na ziemiach polskich w 1. połowie XIII wieku, Archaeologia Historica Polona 23, 2015.

Gawlas S., Uwagi o polityce miejskiej Kazimierza Wielkiego, w: Aetas media, aetas moderna. Studia ofiarowane profesorowi Henrykowi Samsonowiczowi w siedemdziesiątą rocznicę urodzin, Warszawa 2000.

Gąsiorowski, A., Ze studiów nad szerzeniem się tzw. prawa niemieckiego we wsiach ziemi krakowskiej i sandomierskiej (do roku 1333), Roczniki Historyczne 26, 1960.

Gąssowska E., Badania wykopaliskowe w Sandomierzu w latach 1958-1968, Sprawozdania Archeologiczne 22, 1970.

Giergiel T., O męczennikach dominikańskich i sandomierskich podczas najazdu tatarskiego na Sandomierz na przełomie lat 1259 i 1260 oraz o ich kulcie, w: Relikwią ziemi jest w nim... O męczennikach dominikańskich i sandomierskich podczas najazdu tatarskiego na Sandomierz na przełomie lat 1259 i 1260 oraz o ich kulcie, Sandomierz 2016.

Giergiel T., Jop R., Dokument lokacyjny miasta Sandomierza z 1286 roku - forma kancelaryjna, dzieje i edycje, w: T. Giergiel, R. Jop, Dokument lokacyjny Leszka Czarnego dla Sandomierza z 1286 roku, Sandomierz 2015 (Źródła do dziejów Sandomierza 1).

Gliński W., Dominikański kościół św. Marii Magdaleny w Sandomierzu w świetle badań archeologicznych, w: Klasztor w mieście średniowiecznym i nowożytnym, Wrocław-Opole 2006.

Gołubiewowa Z., Kościół dominikański pw. św. Jakuba w Sandomierzu w XIII stuleciu i jego dekoracja architektoniczna, w: Studia nad historią dominikanów w Polsce 1222-1972, t. II, Warszawa 1975. 
Guldon Z., Terytorium, zabudowa i zaludnienie, w: Dzieje Sandomierza, t. II, cz. 2, Warszawa 1993.

Guldon Z., Muszyńska J., Powstanie i dzieje miasta w okresie przedrozbiorowym (do 1795 r.), w: Opoczno. Studia i szkice z dziejów miasta, Kielce 2003.

Gumowski M., Najstarsze pieczęcie miast polskich XIII i XIV wieku, Toruń 1960.

Haisig M., Nieznana pieczęć miasta Sandomierza, Miesięcznik Heraldyczny 17, 1938, z. 9.

Inglot S., Stan i rozmieszczenie uposażenia biskupstwa krakowskiego w połowie XV wieku. Próba odtworzenia zaginionej części Liber beneficiorum Długosza, Lwów 1925.

Kalinowski W., Lalik T., Przypkowski T., Rutkowski H., Trawkowski S., Sandomierz, Warszawa 1956.

Kamińska K., Lokacje na prawie magdeburskim na ziemiach polskich do 1370 r. Studium historycznoprawne, Torun 1990.

Karczewski D., Franciszkanie w monarchii Piastów i Jagiellonów w średniowieczu. Powstanie - rozwój - organizacja wewnętrzna, Kraków 2012.

Kiryk F., Kościół i parafia św. Pawła w Sandomierzu w okresie staropolskim, w: Ecclesia cultura - potestas. Studia z dziejów kultury i społeczeństwa. Księga ofiarowana Siostrze Profesor Urszuli Borkowskiej OSU, Kraków 2006.

Kiryk F., Miasta małopolskie w średniowieczu i czasach nowożytnych, Kraków 2013.

Kiryk F., Rolnictwo, w: Dzieje Sandomierza, t. II, cz. 1, Warszawa 1993.

Kiryk F., Rozwój urbanizacji Małopolski XIII-XVI w. Powiaty południowe, Kraków 1985.

Kiryk F., Urbanizacja Małopolski. Województwo sandomierskie: XIII-XVI wiek, Kielce 1994.

Kłoczowski J., Dominikanie polscy na Śląsku w XIII-XIV wieku, Lublin 1956.

Kozłowska-Budkowa Z., Szczur S., Dzieje opactwa cystersów w Koprzywnicy do końca XIV wieku, Nasza Przeszłość 60, 1983.

Krasnowolski B., Lokacyjne układy urbanistyczne na obszarze ziemi krakowskiej w XIII i XIV wieku, cz. 1-2, Kraków 2004.

Krasnowolski B., Poszerzenie układu urbanistycznego centrum po 1349 roku - analiza modularna, w: Atlas historyczny miast polskich, t. V, z. 2, Sandomierz-Kraków 2014.

Krasnowolski B., Układ urbanistyczny lokacyjnego Sandomierza (1286) - analiza modularna, w: Atlas historyczny miast polskich, t. V, z. 2, Sandomierz-Kraków 2014.

Krzyżanowski J., Polityka miejska Bolesława Wstydliwego, w: Studia historyczne ku czci Stanisława Kutrzeby, t. II, Kraków 1938.

Kulejewska-Topolska Z., Oznaczenia i klasyfikacje miast w dawnej Polsce (XVI-XVIII w.), Czasopismo Prawno-Historyczne 8, 1956, z. 2.

Kunkel M., Mrozowski P., Kościół św. Piotra w Sandomierzu. Analiza historyczno-architektoniczna, w: Sandomierz: badania 1969-1973, t. II, Warszawa 1996.

Kurtyka J., Elita małopolska XIII i XIV w. - przerwa czy kontynuacja (na przykładzie Toporów: potomstwo Żegoty wojewody i kasztelana krakowskiego), w: Genealogia - polska elita polityczna w wiekach średnich na tle porównawczym, Toruń 1993.

Kurtyka J., Odrodzone Królestwo. Monarchia Władysława Łokietka i Kazimierza Wielkiego w świetle nowszych badań, Kraków 2001.

Labuda G., Franciszkanie polscy w źródłach narracyjnych prowincji polsko-czeskiej w średniowieczu, w: Zakony franciszkańskie w Polsce, t. I, cz. 2-3, Lublin 1983.

Lalik T., Domy kanoników kapituły sandomierskiej w średniowieczu, w: Sandomierz: badania 1969-1973, t. I, Warszawa 1992.

Lalik T., Lokacja Sandomierza w 1286 roku, w: Sandomierz: badania 1969-1973, t. I, Warszawa 1992.

Lalik T., Sandomierz w świetle źródeł pisanych, w: Sandomierz: badania 1969-1973, t. I, Warszawa 1992.

Lalik T., Zawichost we wcześniejszym średniowieczu, Kwartalnik Historii Kultury Materialnej 40, 1992, z. 2.

Lapis D., Beginki w Polsce w XIII-XV wieku, Kwartalnik Historyczny 79, 1972.

Lechowicz Z., Zamek w Radomiu. Archeologia i architektura, badania i interpretacje, Radom 2012. 
Luciński J., Lokacje wsi i miast monarszych w Małopolsce do 1385 r., Czasopismo Prawno-Historyczne 17, 1965, z. 2.

Łysiak L., Sąd wyższy prawa niemieckiego na zamku krakowskim a inne sądy wyższe z terenu Małopolski, Śląski Kwartalnik Historyczny Sobótka 48, 1993, z. 2-3.

Marzec A., Geneza stronnictwa „panów krakowskich” w późnośredniowiecznej Polsce, w: Kazimierz Wielki i jego państwo, Bydgoszcz 2011.

Maschke E., Der Peterspfennig in Polen und dem deutschen Osten, wyd. 2, Sigmaringen 1979.

Mazur Z., Dwa dokumenty Leszka Czarnego dla dominikanów sandomierskich, Studia Historyczne $12,1969$.

Mazur Z., Studia nad kancelarią księcia Leszka Czarnego, Wrocław 1975.

Miłobędzki A., Zamek sandomierski, w: Studia sandomierskie. Materiały do dziejów miasta i regionu sandomierskiego, cz. 2, Sandomierz 1967.

Morawski Z., Sandomierz od końca XIII do początków XV wieku, w: Dzieje Sandomierza, t. I, Warszawa 1993.

Morawski Z., Wspólnoty parafialne późnośredniowiecznego Sandomierza, w: Studia nad dziejami miast i mieszczaństwa w średniowieczu, Toruń 1996.

Muszyńska J., Spory miasta Sandomierza z chłopami ze wsi miejskich w XVII i XVIII wieku, w: Księga jubileuszowa Profesora Feliksa Kiryka, Kraków 2004 (Annales Academiae Paedagogicae Cracoviensis 21, Seria Historica 3).

Niewiński A., Przestrzeń kościelna w topografii średniowiecznego Krakowa. Próba syntezy, Lublin 2004.

Niwiński M., Biskup krakowski Bodzanta i Kazimierz Wielki, Collectanea Theologica 17, 1936, z. 1-2.

Nowakowski T., Małopolska elita władzy wobec rywalizacji o tron krakowski w latach 12881306, Bydgoszcz 1992.

Orłowska A., W sprawie polityki handlowej Kazimierza Wielkiego, w: Z dziejów średniowiecznej Europy Środkowo-Wschodniej. Zbiór studiów, cz. 2, Warszawa 2007 (Fasciculi Historici Novi 6).

Orzechowski K., Ogólnośląskie zgromadzenia stanowe, Warszawa-Wrocław 1979.

Otwinowska D., Zbiory pieczęci w muzeum Narodowym w Krakowie i w Bibliotece XX Czartoryskich w Krakowie, w: Zbiory pieczęci w Polsce, Warszawa 2009.

Paszkiewicz B., Kraków, Sandomierz i mennictwo Władysława Łokietka, w: Miasta, ludzie, instytucje, znaki. Księga jubileuszowa ofiarowana Profesor Bożenie Wyrozumskiej w 75. rocznicę urodzin, Kraków 2008.

Paszkiewicz B., Mennictwo Władysława Łokietka, Wiadomości Numizmatyczne 30, 1986, z. 1-2.

Pawłowska-Obara A., Polityka gospodarcza Władysława Łokietka, Lublin 2014.

Pencakowski P., Sanktuaria minoryckie w Zawichoście i Nowym Korczynie. Dwie fundacje związane z księciem Bolesławem Wstydliwym i jego rodziną, Kwartalnik Architektury i Urbanistyki 37, 1992, z. 2.

Piech Z., Ikonografia pieczęci Piastów, Kraków 2003.

Piekalski, J., Od Kolonii do Krakowa. Przemiana topografii wczesnych miast, Wrocław 1999.

Piekalski, J., Praga, Wrocław i Kraków. Przestrzeń publiczna i prywatna w czasach średniowiecznego przełomu, Wrocław 2014.

Piekosiński F., Pieczęcie polskie wieków średnich, cz. 1: Doba piastowska, Kraków 1899.

Pietras T., „Krwawy wilk z pastorałem”. Biskup krakowski Jan zwany Muskatą, Warszawa 2001.

Pleszczyński A., Fundacja opactwa klarysek w Zawichoście w 1245 roku a aspiracje polityczne Bolesława Wstydliwego, w: Klasztor w państwie średniowiecznym i nowożytnym, Wrocław 2005.

Pleszczyński A., Podłoże polityczne i ideowe fundacji Bolesława Wstydliwego dla zakonu klarysek w Zawichoście, w: Peregrinatio ad veritatem. Studia ofiarowane profesor Aleksandrze Witkowskiej OSU z okazji 40-lecia pracy naukowej, Lublin 2004. 
Poklewski T., Miejsce zamku w systemie obronnym miasta w wiekach XIV i XV w Polsce, w: Czas, przestrzeń, praca w dawnych miasta. Studia ofiarowane Henrykowi Samsonowiczowi w sześćdziesiątą rocznicę urodzin, Warszawa 1991.

Poklewski T., Przydatność tekstu Quomodo regebat regnum et populum do badań wielkości inwestycji obronnych Kazimierza Wielkiego, Kwartalnik Architektury i Urbanistyki 40, 1995, z. 1.

Poniewozik L., Prałaci i kanonicy sandomierscy w okresie średniowiecza, Toruń 2004.

Ptak J., Związki Świętej Kingi z Sandomierzem, w: Pani Sądecka. Aktualność Świętej Kingi, Sandomierz 2000.

Ptak M., Zgromadzenia i urzędy stanowe księstwa głogowskiego od początku XIV w. do 1742, Wrocław 1991.

Ptaśnik J., Studia nad patrycjatem krakowskim wieków średnich, cz. 1, Rocznik Krakowski $15,1913$.

Rajman J., Krakowska civitas sołtysów Piotra i Salomona, w: Społeczeństwo Polski średniowiecznej, t. XII, Warszawa 2012.

Rajman J., Kraków. Zespół osadniczy, proces lokacji i mieszczanie do roku 1333, Kraków 2004.

Rębkowski M., Pierwsze lokacje miast w Księstwie Zachodniopomorskim. Przemiany przestrzenne i kulturowe, Kołobrzeg 2001.

Rokosz M., „Sigillum regis... et civitatis”. O pieczęci wielkiej Sandomierza, w: Heraldyka i okolice, Warszawa 2002.

Rutkowska-Płachcińska A., Gmina miejska w początkach XIII w. w Polsce, w: Wieki średnie - medium aevum. Prace ofiarowane Tadeuszowi Manteufflowi w 60. rocznicę urodzin, Warszawa 1962.

Rutkowska-Płachcińska A., Podanie o Piotrze z Krępy w świetle rękopisów Rocznika świętokrzyskiego nowego oraz późniejszych przekazów, w: Mente et litteris. O kulturze i społeczeństwie wieków średnich, Poznań 1984.

Rutkowska-Płachcińska A., Sprawy tatarskie w Roczniku tak zwanym świętokrzyskim nowym: podkład źródłowy i warstwa anegdotyczna, Studia Źródłoznawcze 30, 1987.

Rutkowski H., Z dziejów Sandomierza w okresie Odrodzenia, w: Studia sandomierskie. Materiały do dziejów miasta i regionu sandomierskiego, cz. 2, Sandomierz 1967.

Rymaszewski Z., Łacińskie teksty Landrechtu Zwierciadła Saskiego w Polsce. Versio Vratislaviensis, versio Sandomiriensis, Łaski, Wrocław 1975.

Samsonowicz H., Przemiany osi drożnych w Polsce późnego średniowiecza, Przegląd Historyczny 64, 1973.

Samsonowicz H., Bogucka M., Dzieje miast i mieszczaństwa w Polsce przedrozbiorowej, Wrocław 1986.

Sandomierz: badania 1969-1973, t. I-II, red. S. Tabaczyński, Warszawa 1992-1996 (Polskie badania archeologiczne 31-32).

Seroka H., Herby miast małopolskich do końca XIII wieku, Warszawa 2002.

Seroka H., Herby miasta królewskiego Sandomierza, Sandomierz 2016.

Skupieński K., Klasztory a początki dokumentu miejskiego w Polsce, w: Klasztor w mieście średniowiecznym i nowożytnym, Wrocław-Opole 2006.

Słoń M., Fundatio civitatis. Porgram fundacyjny procesu lokacyjnego na przykładzie Wrocławia, Krakowa i Poznania, w: Procesy lokacyjne miast w Europie Środkowo-Wschodniej, Wrocław 2006.

Stan badań archeologicznych miast w Polsce, red. H. Paner, M. Fudziński, Z. Borcowski, Gdańsk 2009.

Starnawska M., Między Jerozolimą a Łukowem. Zakony krzyżowe na ziemiach polskich w średniowieczu, Warszawa 1999.

Starzyński M., Krakowska rada miejska w średniowieczu, Kraków 2010.

Starzyński M., Uwagi w sprawie genezy najstarszej pieczęci Krakowa z XIII wieku (na marginesie ostatnich badań), Studia Źródłoznawcze 50, 2012. 
Stępkowski L., Biskup Adam Naruszewicz o chronologii przywileju lokacji Sandomierza z 1286 roku, Zeszyty Sandomierskie 18, 2004.

Stopka K., Męczennicy sandomierscy. Legenda i rzeczywistość, Nasza Przeszłość 80, 1993.

Studia sandomierskie. Materiały do dziejów miasta i regionu sandomierskiego, cz. 1-2, red. T. Wąsowicz, J. Pazdur, Sandomierz 1967.

Studien zur Geschichte des sächsisch-magdeburgischen Rechts in Deutschland und Polen, red. D. Willoweit, W. Schich, Frankfurt a.M. 1980.

Szacherska S. M., Płock - civitas vetus czy civitas cathedralis?, w: Społeczeństwo Polski średniowiecznej, t. V, Warszawa 1992.

Szczur S., Supliki Kazimierza Wielkiego, Roczniki Historyczne 59, 1993, s. 43-91.

Szczur S., W sprawie sukcesji andegaweńskiej w Polsce, Roczniki Historyczne 75, 2009.

Szczygieł R., Powstanie nowego Nowego Miasta w Radomiu, w: Radom. Lokacja miasta, odkrywanie zamku, Radom 2001.

Świętochowski R. OP, Sadok i 58 męczenników sandomierskich, w: Hagiografia polska. Słownik bio-bibliograficzny, t. II, Poznań 1972.

Tabaczyński S., Wprowadzenie, w: Sandomierz: badania 1969-1973, t. I, Warszawa 1992.

Teterycz-Puzio A., Geneza województwa sandomierskiego. Terytorium i miejsce w strukturze państwa polskiego w średniowieczu, Słupsk 2001.

Teterycz-Puzio A., Kilka uwag o działalności politycznej księżnych krakowskich w okresie rozbicia dzielnicowego, Res Historica 26, 2008.

Třeštík D., Formularze czeskie XIII wieku. Rękopisy i filiacje, Studia Źródłoznawcze 7, 1962.

Urzędnicy małopolscy XII-XV wieku. Spisy, Wrocław 1990.

Wąsowicz T., Sandomierska sieć drożna w wiekach średnich, w: Studia sandomierskie. Materiały do dziejów miasta i regionu sandomierskiego, cz. 1, Sandomierz 1967.

Weymann S., Cła i drogi handlowe w Polsce piastowskiej, Poznań 1938.

Wędzki A., Początki reformy miejskiej w Środkowej Europie do połowy XIII wieku, Poznań 1974.

Widawski J., Miejskie mury obronne w państwie polskim do początku XV wieku, Warszawa 1973.

Widawski J., Zamek i mury miejskie Inowłodza na tle podobnych obiektów w Polsce, w: Problemy badawcze średniowiecznego Inowłodza, Łódź 1980.

Wojciechowski P. K., Ugrupowania polityczne w ziemiach krakowskiej i sandomierskiej w latach 1280-1286, Przegląd Historyczny 70, 1979.

Wyrozumska B., Otto z Pilicy, w: Polski słownik biograficzny, t. XXIV, Wrocław 1979.

Wyrozumski J., Kraków do schyłku wieków średnich, Kraków 1992 (Dzieje Krakowa, t. I).

Wyrozumski J., Początki miast w regionie jasielskim, w: Studia z dziejów Jasła i powiatu jasielskiego, Kraków 1964.

Wyrozumski J., Rozwój sieci miejskiej w Małopolsce w średniowieczu i u progu czasów nowożytnych, Kwartalnik Historii Kultury Materialnej 28, 1980, z. 3.

Wyrzykowski J., Buliński Melchior, w: Polski słownik biograficzny, t. III, Kraków 1937.

Zarębska T., Z zagadnień urbanistycznych Inowłodza, w: Problemy badawcze średniowiecznego Inowłodza, Łódź 1980.

Zientara B., Przełom w rozwoju miast środkowoeuropejskich w pierwszej połowie XIII wieku, Przegląd Historyczny 67, 1976, z. 2.

Zientara B., Przemiany społeczno-gospodarcze i przestrzenne miast w dobie lokacji, w: Miasta doby feudalnej w Europie Środkowo-Wschodniej. Przemiany społeczne a układy przestrzenne, Warszawa 1976.

Żebrawski T., O pieczęciach dawnéj Polski i Litwy, Kraków 1865.

Żemigała M., Datowanie planu miasta Kalisza w świetle najnowszych badań archeologicznych, Kwartalnik Architektury i Urbanistyki 38, 1993, z. 2.

Żmudzki P., Studium podzielonego Królestwa. Książę Leszek Czarny, Warszawa 2000. 


\section{Die wichtigsten Entwicklungsetappen der Lokationsstadt Sandomir im 13.-14. Jahrhundert}

\section{Zusammenfassung}

Seit den 1950er Jahren ist die Geschichte des mittelalterlichen Sandomir Gegenstand systematischer Forschungen von Historikern und Archäologen. Die Ergebnisse dieser Untersuchungen fanden in zahlreichen Veröffentlichungen ihren Niederschlag, die sich durch Mannigfaltigkeit der Thesen, Perspektiven und Forschungswerkzeuge unterscheiden. Das Ziel dieses Beitrags ist es, den bisherigen Forschungsstand zur Entwicklung der Lokationsstadt Sandomir im 13.14. Jahrhundert zusammenzufassen sowie einige in der bisherigen Literatur vorkommende Feststellungen und Interpretationen einer Überprüfung zu unterziehen. Viele dieser Ansichten wurden aus der ersten Monographie zur Geschichte Sandomirs, die der Sandomirer Kanoniker und Historiker M. Buliński 1879 verfaßte, unkritisch übernommen. Der Autor des Beitrags stellt sich ebenfalls die Aufgabe, die Geschichte der mittelalterlichen Stadtaussetzung in vergleichender Perspektive und vor dem Hintergrund der Urbanisierung Polens im Rahmen der sog. Besiedlung nach deutschem Recht darzustellen. Die genaue Analyse aller zur Verfügung stehenden Quellenzeugnisse zur Geschichte Sandomirs erlaubt es, die Lokation der Stadt als einen zeitlich ausgedehnten Prozeß aufzuzeigen. Als ersten Schritt kann man die Ausbildung einer Gemeinde deutscher Kaufleute an der Kirche St. Paul auf den Altstadthügeln im ersten Viertel des 13. Jahrhunderts, höchstwahrscheinlich in der Herrschaftszeit Leszeks des Weißen († 1227), ausmachen. Die zweite, quellenmäßig am besten beleuchtete Etappe bestand in der Verlegung der ursprünglichen Siedlung auf die Stadthügel sowie ihre rechtliche und flächenmäßige Umsetzung nach Magdeburger Recht im Jahre 1286 durch Herzog Leszek den Schwarzen. Die dritte, schwächer erforschte Phase in der Entwicklung der Lokationsstadt fällt in die Herrschaftszeit Kasimirs des Großen. Die damals eingeführten Neuerungen standen mit der erstarkten Stellung der Stadt innerhalb der Fernhandelswege im Zusammenhang und kamen in der Erweiterung der Stadtfläche sowie der Errichtung der Stadtmauer und der Burg zum Ausdruck. Das Vorgehen des Königs begünstige wohl auch die Ausweitung der Befugnisse der Selbstverwaltung. Alle drei aufgezeigten Etappen im Aussetzungsprozeß der Stadt verliefen entsprechend den damaligen Standards der Städtepolitik und riefen folglich den Widerstand kirchlicher Einrichtungen hervor.

Übersetzt von Waldemar Könighaus

\section{Main stages of forming the locational town in Sandomierz in the 13th-14th centuries}

\section{Abstract}

The paper presents an attempt at summing up and verification of the current state of research on the location of medieval Sandomierz. The author shows that town location as a long-lasting process, consisting of a number of stages: 1. creating a trade community in Old Town Hills in the first quarter of the $13^{\text {th }}$ century; 2 . moving the settlements to the Town Hill in 1286 , together with defining regular building layout; 3 . expansion of the town and its economic and legal stabilisation about mid- $14^{\text {th }}$ century.

Translated by Rafat T. Prinke

dr Piotr Okniński, Zakład Studiów Średniowiecznych, Instytut Historii, Polska Akademia Nauk, Rynek Starego Miasta 29/31, 00-272 Warszawa, e-mail: p.okninski89@gmail.com 


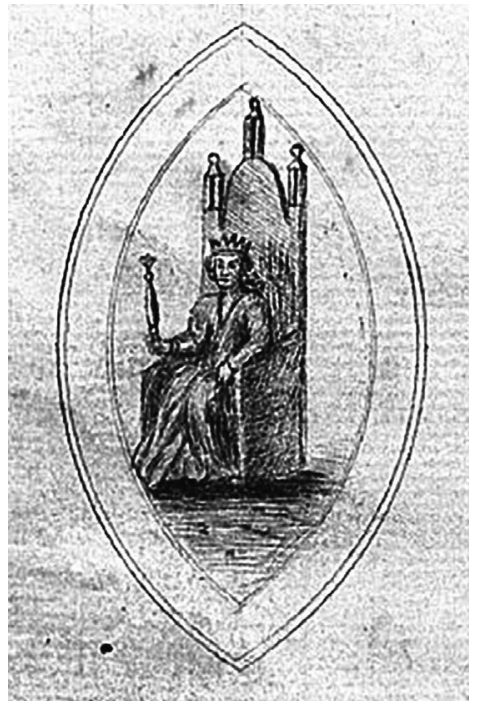

1. Odrys rzekomej pieczęci Sandomierza w kopiarzu, powstały zapewne przed połową XIX w. (według: T. Giergiel, R. Jop, Dokument lokacyjny, s. 27).

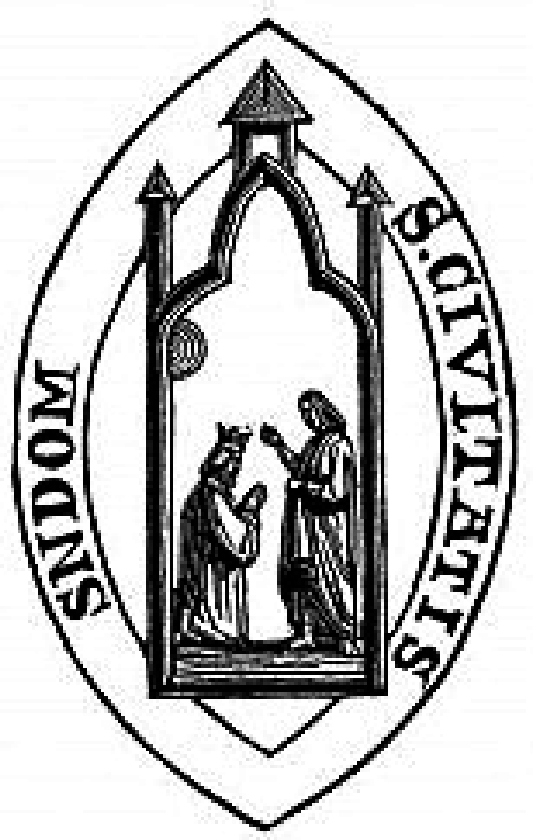

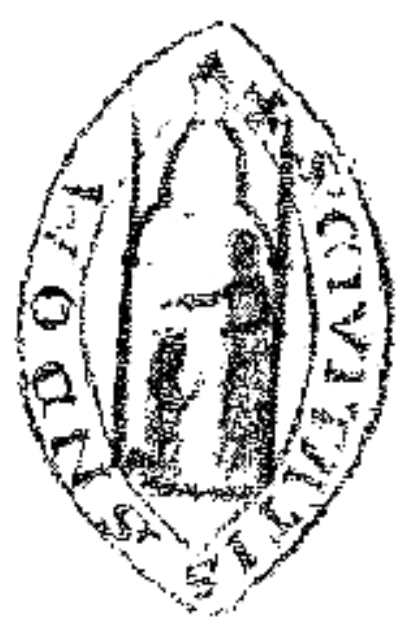

3. Rysunek rzekomej pieczęci Sandomierza (według: M. Gumowski, Najstarsze pieczęcie, tab. 30, nr 381).

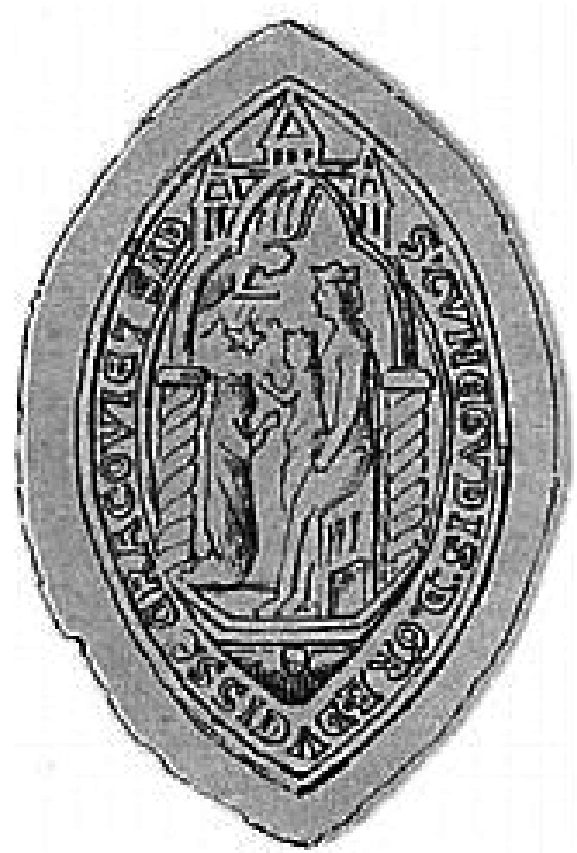

2. Po lewej: odrys rzekomej pieczęci Sandomierza (według: M. Baliński, T. Lipiński, Starożytna Polska, t. II, s. 269); po prawej: odrys pieczęci Kingi na podstawie egzemplarza z $1266 \mathrm{r}$. (według: T. Żebrawski, O pieczęciach dawnej Polski i Litwy, Kraków 1865, s. 26, tab. 4, nr 13). Zestawienie według: M. Starzyński, Uwagi w sprawie genezy, s. 33. 


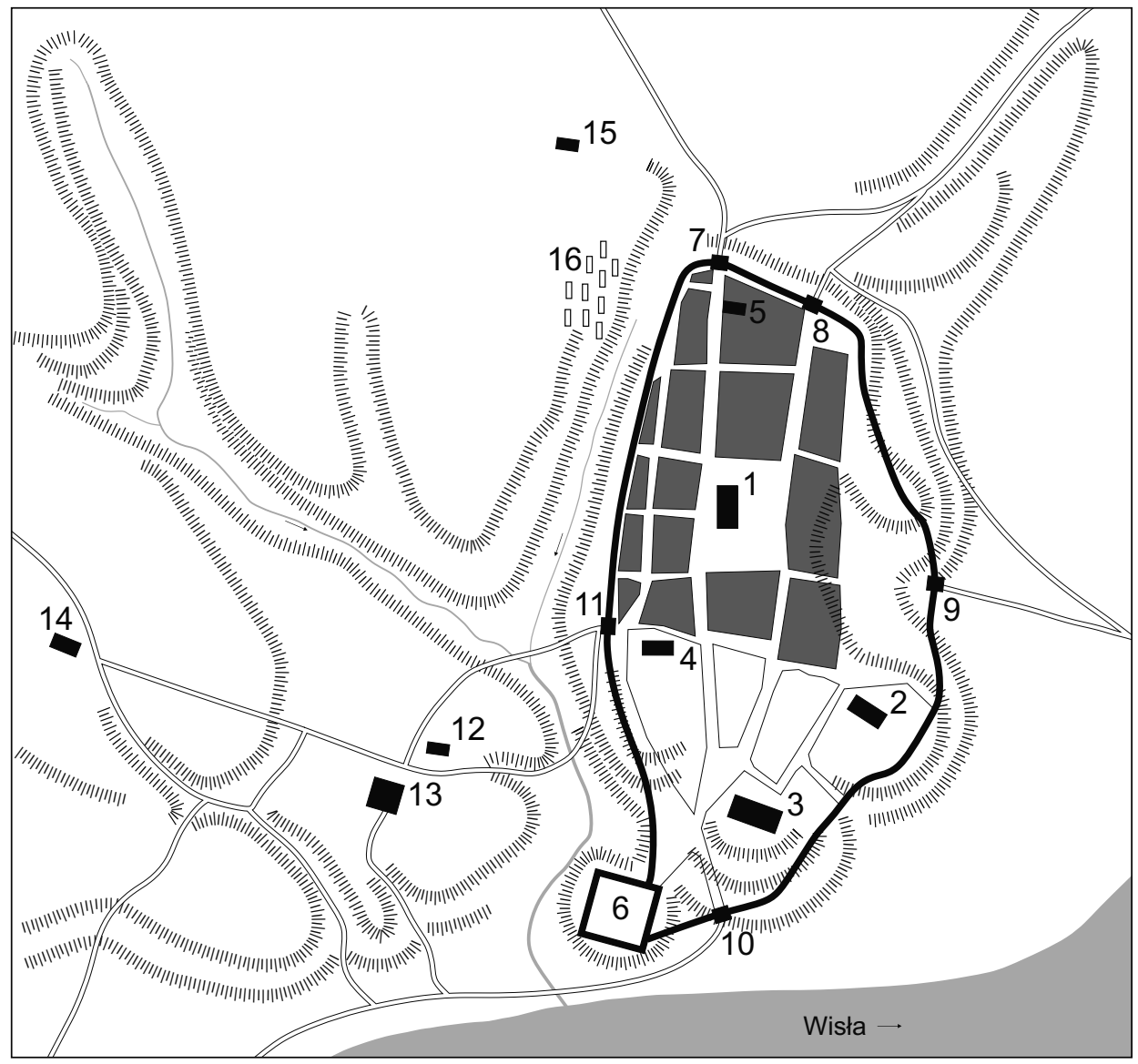

4. Sandomierz za panowania Kazimierza Wielkiego (rys. Tomasz Gidaszewski na podstawie: M. Florek, Sandomierski ośrodek, ryc. 24): 1 - ratusz; 2 - kościół św. Piotra; 3 - kolegiata NMP; 4 - kościół św. Marii Magdaleny i klasztor dominikański; 5 - kościół św. Ducha i zespół szpitalny; 6 - zamek; 7 - Brama Opatowska; 8 - Brama Zawichojska; 9 - Brama Lubelska (Rybacka); 10 - Brama Krakowska; 11 - baszta bramna; 12 - kościół (kaplica) św. Jana; 13 - kościół św. Jakuba i klasztor dominikański; 14 - kościół św. Pawła; 15 - kościół św. Wojciecha; 16 - cmentarz żydowski. 